\title{
Archaeological Investigations at the Edwards Creek Site (41FT549) in the Trinity River Basin, Freestone County, Texas
}

Timothy K. Perttula

Heritage Research Center, Stephen F. Austin State University

Bo Nelson

Heritage Research Center, Stephen F. Austin State University

Mark Walters

Heritage Research Center, Stephen F. Austin State University

LeeAnnaa Schniebs

Follow this and additional works at: https://scholarworks.sfasu.edu/ita

Part of the American Material Culture Commons, Archaeological Anthropology Commons, Environmental Studies Commons, Other American Studies Commons, Other Arts and Humanities Commons, Other History of Art, Architecture, and Archaeology Commons, and the United States History Commons

Tell us how this article helped you.

This Article is brought to you for free and open access by the Center for Regional Heritage Research at SFA ScholarWorks. It has been accepted for inclusion in Index of Texas Archaeology: Open Access Gray Literature from the Lone Star State by an authorized editor of SFA ScholarWorks. For more information, please contact cdsscholarworks@sfasu.edu. 


\section{Archaeological Investigations at the Edwards Creek Site (41FT549) in the Trinity River Basin, Freestone County, Texas \\ Creative Commons License \\ (c) (1) (8)}

This work is licensed under a Creative Commons Attribution-NonCommercial 4.0 International License 


\title{
ARCHAEOLOGICAL INVESTIGATIONS AT THE EDWARDS CREEK SITE (41FT549) IN THE TRINITY RIVER BASIN, FREESTONE COUNTY, TEXAS
}

\author{
Timothy K. Perttula, Bo Nelson, and Mark Walters, \\ with a contribution by LeeAnna Schniebs
}

\section{INTRODUCTION}

The Edwards Creek site (41FT549) was found during the course of a 2005 archaeological survey of a proposed small lake project in the adjoining Indian Creek stream valley in southeastern Freestone County, Texas (Perttula and Nelson 2005). The site was identified while reconnoitering the general project area, and at that time a darkly stained midden area was noted on the surface here, with animal bones and other artifacts visible across it. With the permission of the landowner, we returned to the Edwards Creek site to investigate the site and its midden deposits

\section{NATURAL AND CULTURAL SETTING}

The Edwards Creek site is located in southeastern Freestone County, Texas. It is situated on Edwards Creek, a small tributary that drains northnortheast to its confluence with the Trinity River about $3 \mathrm{~km}$ away. The project area is located within the West Gulf Coastal Plain physiographic province (Fenneman 1938:100-103; Carr 1969).

The surface geology in this part of the Trinity River basin consists of Late Pleistocene-age fluviatile terrace deposits (Bureau of Economic Geology 1968) on the north and east sides of the river, with Quaternary alluvium along the Trinity River floodplain and on tributaries like Edwards Creek. Upland ridges are part of the Eocene Reklaw Formation. This formation is a ca. 30-130 ft. thick deposit of clay, silt, glauconitic ironstone, and calcite.

Edwards Creek is a relatively shallow dissecting drainage, and its channel lies around ca. 245-250 ft. amsl; there is a boggy floodplain area on the north side of the creek just across from the site. The creek floodplain is $100-130 \mathrm{ft}$. lower than the surrounding rocky upland ridges, which crest at $380 \mathrm{ft}$. amsl. The Edwards Creek site itself is at $245-270 \mathrm{ft}$. amsl (Figure 1), on a lower toe slope and small alluvial fan.

The sediments on the landform are Cuthbert gravelly fine sandy loam and Wolfpen loamy fine sand (Janak and Griffin 2002). These soils have fine sandy loam and loamy fine sand A- and E- horizons as much as $1 \mathrm{~m}$ in thickness over deep $\mathrm{B}$ and $\mathrm{C}$ horizons of red and yellowish-red clay. In the floodplain are Nahatche series sediments, a loamy soil found along streams that drain forested 


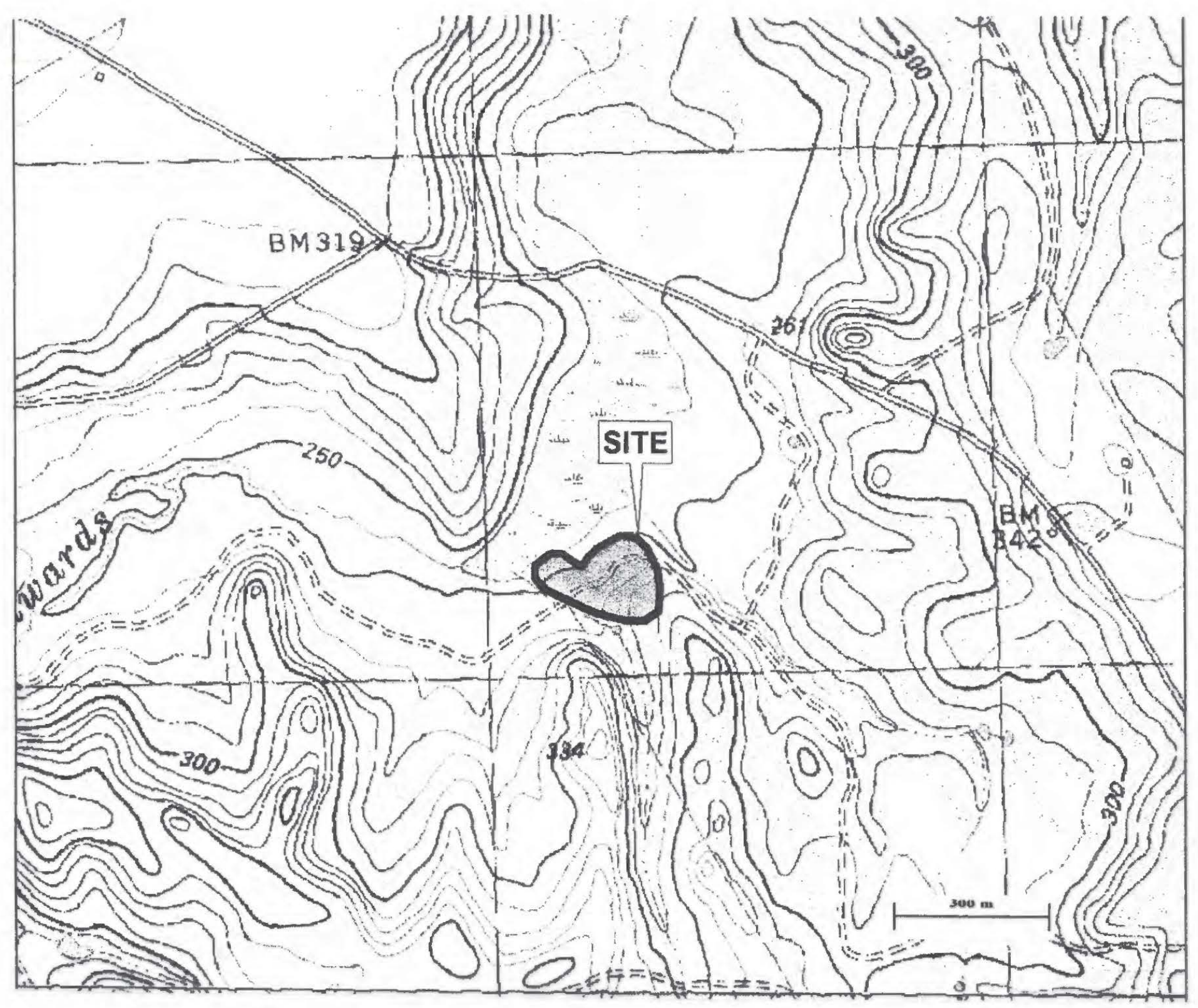

Figure 1. Location of the Edwards Creek site (41FT549), Butler 7.5' topographic quadrangle.

areas on the eastern and western sides of this part of the Trinity River basin. This soil is a brown to dark grayish-brown clay loam to loam, and buried horizons have been noted at depths greater than $1 \mathrm{~m}$ below surface (cf. Coffee 1975:31).

This part of Freestone County lies within the Oak-Hickory Forest Vegetation Region as defined by Arbingast et al. (1976:13; see also Diamond et al. 1987; Schmidly 2002), also known as the Post Oak Savannah. Principal overstory trees prior to modern farming and timber harvesting activities included 
post oak, blackjack oak, and black hickory in upland forests, with an understory dominated by mid- and tall grasses (Richner and Lee 1977:Figure 5). Bottomland forests along the Trinity River and its tributaries were more mesic, and would have included oaks, elm, hackberry, cottonwood, ash, black willow, and pecan, with an understory of briars, vines, sedges, and various grasses.

In the general area, wooded areas with mature timber have post oak, blackjack oak, and winged elm, with an understory of poison ivy, grape, and greenbrier. Sweet gum, persimmon, and black hickory are also present, along with the same understory as the more mature wooded habitats. Along Edwards Creek itself, the vegetation is more mesic, with water oak, black willow, sugarberry, cottonwood, and some pecan trees, and a variety of shrubs, bushes, vines, and briers.

Freestone County is located in the Northeast Texas Archeological Study Region defined by the Texas Historical Commission (Kenmotsu and Perttula 1993). Much of the previous archeological investigations in the immediate area of the Edwards Creek site was done as part of the proposed Tennessee Colony Lake and a 1970s Trinity River multiple-use plan on the Trinity River (see Richner 1982; Richner and Bagot 1978; Richner and Lee 1976, 1977), and the smaller Richland-Chambers Reservoir to the north in Navarro and northern Freestone counties (see McGregor and Bruseth 1987). The proposed Tennessee Colony Lake dam site spanned the Trinity River just north of its confluence with Catfish Creek, not far to the north. During these investigations along the Trinity River, more than 300 prehistoric and historic archeological sites were recorded, and a number of them received limited test excavations to evaluate their research significance (see summary in Richner and Bagot 1978:243-249).

Freestone County is an area of Northeast Texas settled first by mobile hunter-gatherers or foragers as early as 12,000 years ago, but after about 2000 2500 years ago, the prehistoric Native Americans began to settle down in small hamlets and camps in recognizable territories throughout Northeast Texas (Perttula et al. 1993). These Native Americans made sandy paste pottery, and used Gary and Kent dart points for hunting and other tasks.

The principal occupation of Freestone County in prehistoric times was by Caddoan-speaking groups who lived in settled communities in the eastern half of the county (e.g., Story 1990). Small Caddo settlements (with middens and occasionally small cemeteries) are also known in the middle stretches of the Trinity River basin, dating mostly to earlier (ca. A. D. 800-1400) portions of the Late Prehistoric period (Richner 1982:206), but later (after A.D. 1400) prehistoric sites are reported in the general area of the Edwards Creek site. In fact, Richner (1982:206) notes that Late Caddo ceramics have been reported from several prehistoric sites along the Catfish Creek drainage a few miles to the northeast, but on the eastern side of the Trinity River valley. These Late Prehistoric sites in the middle Trinity River basin tend to occur on low terrace remnants and floodplain 
rises, and terraces and upland landforms were not intensively used (Richner 1982:207).

In historic times, Freestone County has been primarily rural in character, with an agricultural economy based through much of the 19th and early 20th century on cotton production (see Richner and Lee 1977:49-50). After about 1940 , with the development of mechanical cotton-pickers and the ready availability of new energy sources from fossil fuels, farms in the area began to be consolidated into fewer but larger farms, and livestock production became a mainstay of the rural agribusiness economy (Richner and Lee 1977:50). The population of Freestone County steadily increased from ca. 1850 to 1940 , then began to decrease in size as many people left the farms and moved to larger urban areas in Texas.

\section{SUMMARY OF THE ARCHAEOLOGICAL INVESTIGATIONS}

Our archaeological investigations at the Edwards Creek site consisted of a general surface collection in exposed areas (i.e., gopher mounds with darklystained sediments) in a pasture as well as the excavation of 24 shovel tests across the toe slope and alluvial fan landform (Figure 2). The site covers a ca. $130 \mathrm{~m}$ (north-south) x $225 \mathrm{~m}$ (east-west) area, or 29,250 square meters (7.2 acres), but the density of artifacts, as discussed below, indicates that the occupation or occupations at the site were concentrated in a small area at the eastern and higher part of the toe slope.

Twenty-two of the 24 shovel tests contain archaeological deposits. Only ST 21 and ST 23 (see Figure 2) on the northern part of the landform were sterile. Not including animal bone ( $\mathrm{n}=102$ from 11 shovel tests) and mussel shell umbo fragments ( $n=4$ from two shovel tests), a total of 173 artifacts were recovered in our work at the Edwards Creek site, possibly from two or perhaps three different components: the first dating to the Woodland period, a second one dating to sometime after the $14^{\text {th }}$ century A.D., and the third dating to the first part of the $19^{\text {th }}$ century. As we will discuss below, it is possible that much of the archeological deposits and aboriginal and historic artifacts found at the site may all be from the early $19^{\text {th }}$ century occupation, with some minor use of the site in Woodland and Early Caddo times.

\section{Archaeological Deposits}

The shovel testing at the Edwards Creek site indicated that there is an extensive but buried midden deposit at the eastern part of the site (above $260 \mathrm{ft}$. amsi). Midden deposits were identified in ST 1, ST 3, ST 12, ST 15, ST 17, and ST 22 (see Figure 2). This midden covers approximately 800 square meters (ca. $38 \mathrm{~m}$ north-south and $21 \mathrm{~m}$ east-west). 


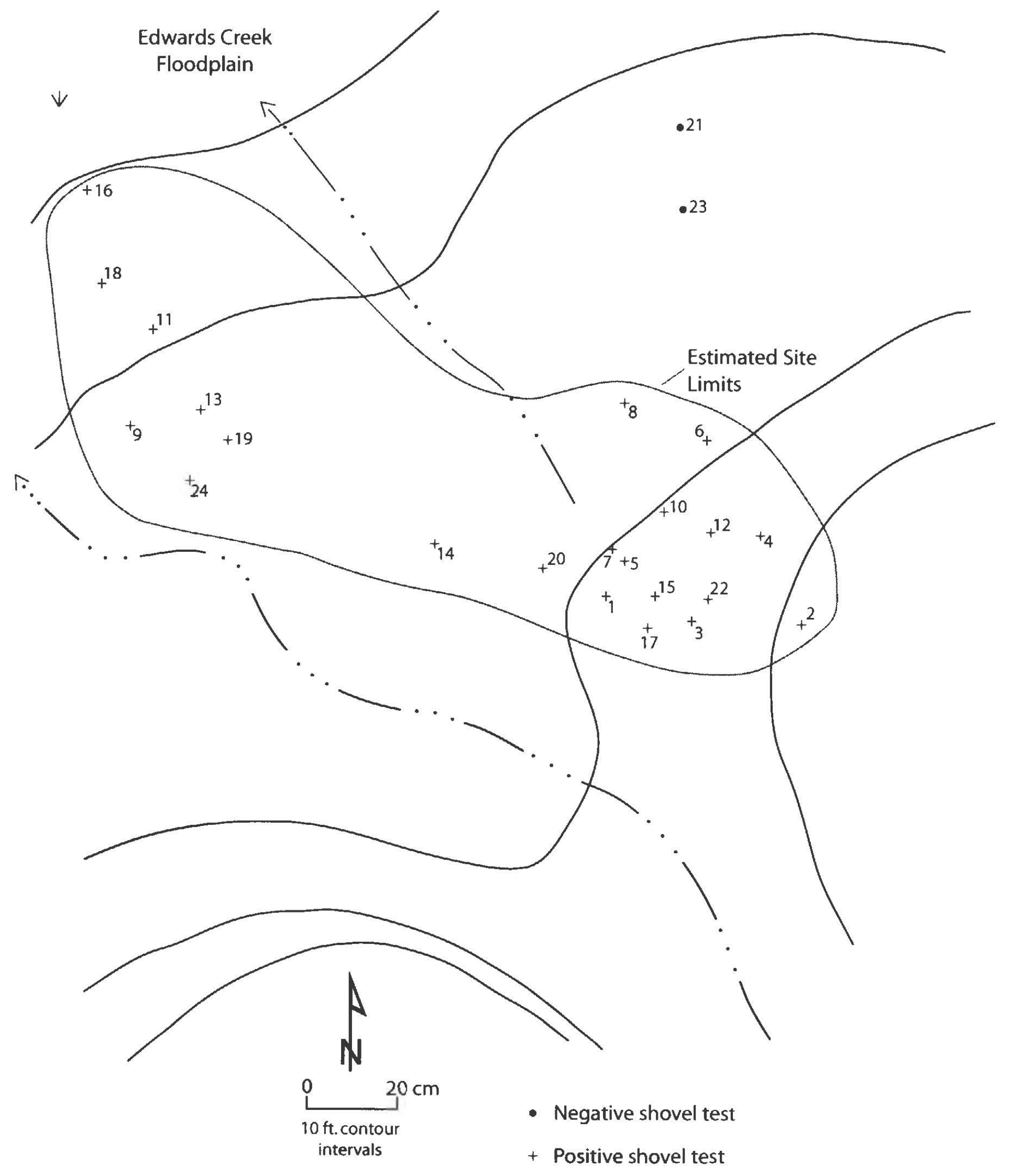

Figure 2. Location of shovel tests on the Edwards Creek site. 
In the area of the midden deposits, shovel tests indicate that the top of the midden - a very dark grayish-brown fine sandy loam with charcoal staining and bone flecks - is buried between $20-55 \mathrm{~cm}$ bs by dark yellowish-brown A-horizon sediments. A yellowish-brown fine sandy loam E-horizon underlies the midden to depths of ca. $80-100 \mathrm{~cm}$ bs or more, except in ST 22, where the midden rests atop a strong brown clay B-horizon. Outside the midden, the $\mathrm{A}$ - and E-horizon sediments are shallower, ca. 30-60 cm thick, overlying the B-horizon.

The midden ranges from $7 \mathrm{~cm}$ in thickness in ST $15(20-27 \mathrm{~cm}$ bs) to 50 $\mathrm{cm}$ in thickness in ST 22 (41-91 cm bs), although there may be a pit feature in this general area that may account for the great depth of the midden here. In the other four midden shovel tests, the midden is $21-39 \mathrm{~cm}$ thick.

A cultural feature, probably an outdoor hearth or earth oven, was identified in ST 17. This consisted of an ash layer between $65-75 \mathrm{~cm}$ bs and a 5 $\mathrm{cm}$ thick $(75-80 \mathrm{~cm}$ bs) thermally altered soil immediately below the ash, probably both in a large pit. The feature was recognized at the base of midden deposits. Other than one piece of lithic debris and 24 pieces of animal bone, the only artifacts found in this shovel test date to the early $19^{\text {th }}$ century (see Tables 1 and 2 , below). Thus, this probable hearth or earth oven feature likely dates to early historic times and was subsequently buried. Similar features have been described by Jurney (1992:58-59 and 65-66) from the Bottoms Farmstead (4IFT89), a ca. 1856-1868 farmstead occupied by a family with Choctaw Indian ancestry. Jurney (1992:66) suggests that such features - characterized by lenses of ash and charcoal as well as heat-altered sediments - were used for outdoor cooking of food stuffs, especially in hot weather. Jurney further suggests that outdoor cooking features were frequently used by Native Americans living in the southeastern United States, hinting that the features at the Bottoms site were used by peoples with a Native American ancestry. Such may also have been the case with the ST 17 feature at the Edwards Creek site.

\section{Recovered Archaeological Materials}

The 173 artifacts found at the Edwards Creek site during our investigations includes 53 from the surface and 120 from the 22 positive shovel tests (Tables 1 and 2 ). The mean density of artifacts is 5.45 per positive shovel test (not including animal bone or mussel shell), approximately 44 artifacts per square meter across the site. The range in artifacts per shovel test is 1-17, with the highest densities in ST $7(n=17)$, ST $22(n=13)$, ST $3(n=12)$, ST $17(n=12)$, and ST $5(n=10)$; three of these shovel tests are in the midden deposits (see Figure 2). 
Table 1. Historic artifacts recovered from the Edwards Creek site.

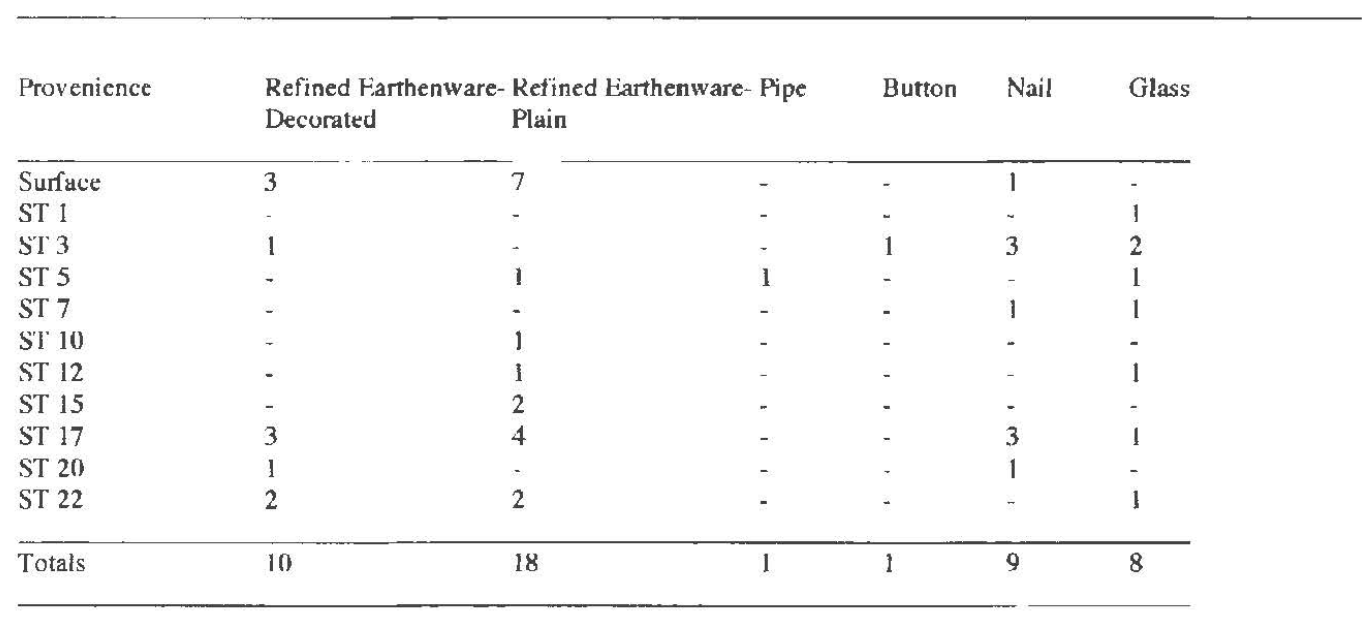

Table 2. Aboriginal artifacts recovered from the Edwards Creek site.

\begin{tabular}{lllllll}
\hline Provenience & $\begin{array}{l}\text { Lithic } \\
\text { Debris }\end{array}$ & $\begin{array}{l}\text { Arrow } \\
\text { Point }\end{array}$ & $\begin{array}{l}\text { Dart } \\
\text { Point }\end{array}$ & $\begin{array}{l}\text { Ceramic } \\
\text { Sherd }\end{array}$ & Bumed Clay & Chipped Stone Tool \\
\hline Surface & 32 & 1 & 2 & 3 & 3 & 1 \\
ST 1 & 3 & - & - & - & - & - \\
ST 2 & 2 & - & - & - & - & - \\
ST 3 & 3 & - & - & 2 & - & - \\
ST 4 & 2 & - & - & - & - & - \\
ST 5 & 6 & - & - & - & - & 1 \\
ST 6 & 3 & - & - & - & - & - \\
ST 7 & 12 & - & - & - & 3 & - \\
ST 8 & 2 & - & 1 & 2 & - & - \\
ST 9 & 3 & - & - & - & - & - \\
ST 10 & 5 & - & - & - & - & - \\
ST 11 & 4 & - & - & 1 & - & - \\
ST 12 & 2 & 1 & - & - & - & - \\
ST 13 & 1 & - & - & - & - & - \\
ST 14 & 1 & - & - & - & - & - \\
ST 15 & 3 & - & - & 1 & - & - \\
ST 16 & 1 & - & - & - & - & - \\
ST 17 & 1 & - & - & - & - & - \\
ST 18 & 1 & - & - & - & - & - \\
ST 19 & 2 & - & - & - & - & - \\
ST 20 & 2 & - & - & 1 & - & - \\
ST 22 & 4 & - & - & 1 & - & - \\
ST 24 & 2 & - & - & - & - & - \\
\hline Totals & 97 & 2 & 3 & 11 & - & - \\
\hline & & & & & - & - \\
\hline
\end{tabular}


Early $19^{\text {th }}$ century artifacts were recovered from 10 of the shovel tests (Figure 3 and Table 1), and in these shovel tests, historic artifacts have a mean density of 3.6 artifacts per positive shovel test (ca. 29 artifacts per square meter). The range per shovel test is 1-11, with the highest densities in ST $17(n=11)$ and ST $3(n=7)$, both in the midden deposits. The area with early $19^{\text {th }}$ century artifacts extends over a ca. 1230 square meter area, primarily an area associated with the midden deposits.

Aboriginal lithic and/or ceramic artifacts were found in all 22 shovel tests. Lithic artifacts are concentrated in two areas, in the midden and then at a lower elevation on the toe slope/alluvial fan (Figure 4). These two areas cover ca. 1510 square meters and 470 square meters, respectively. The larger area overlaps with, and is adjacent to the midden deposits. The aboriginal ceramics-Caddo utility wares-are found in the same two areas (Figure 5), but appear to be concentrated in the midden. This area with aboriginal Caddo sherds (from three positive shovel tests) is about 310 square meters in extent.

The density of aboriginal artifacts is 3.8 per positive shovel test (ca. 30 artifacts per positive shovel test). The highest densities occur in ST $7(n=15)$, ST $22(n=8)$, ST $5(n=7)$, and ST $10(n=6)$; half of these are in the midden (see Figures 4 and 5).

In the midden itself, the majority of the artifacts (including animal bones) are found from $20-80 \mathrm{~cm}$ bs (Table 3 ). The highest frequency of artifacts, however, is between $60-80 \mathrm{~cm}$ bs and $20-40 \mathrm{~cm}$ bs, which corresponds to the top and bottom of the midden deposits. The most common archaeological materials in the midden are early $19^{\text {th }}$ century artifacts, animal bone, and lithic debris.

Table 3. Artifacts found in the midden at the Edwards Creek site.

$\begin{array}{lllllll}\text { Depth } & \text { Historic Caddo } & \text { Lithic } & \text { Stone } & \text { Animal bone- } & \text { BC } & \text { N } \\ \text { Artifacts Sherds } & \text { Debris } & \text { Tool } & \text { Mussel shell } & & \end{array}$

\begin{tabular}{llllllll}
\hline $0-20 \mathrm{~cm}$ & 3 & 2 & 4 & - & 4 & - & 13 \\
$20-40 \mathrm{~cm}$ & 9 & - & 5 & - & 16 & - & 30 \\
$40-60 \mathrm{~cm}$ & 7 & 1 & 2 & - & 13 & 2 & 25 \\
$60-80 \mathrm{~cm}$ & 8 & 1 & 4 & 1 (AP) 35 & - & 49 \\
$80-100 \mathrm{~cm}$ & 1 & - & 1 & - & 9 & - & 11 \\
\hline
\end{tabular}

$\begin{array}{lllllllll}\text { Totals } & 28 & 4 & 16 & 1 & 77 & 2 & 128\end{array}$

$\mathrm{BC}=$ burned clay; $\mathrm{AP}=$ arrow point 


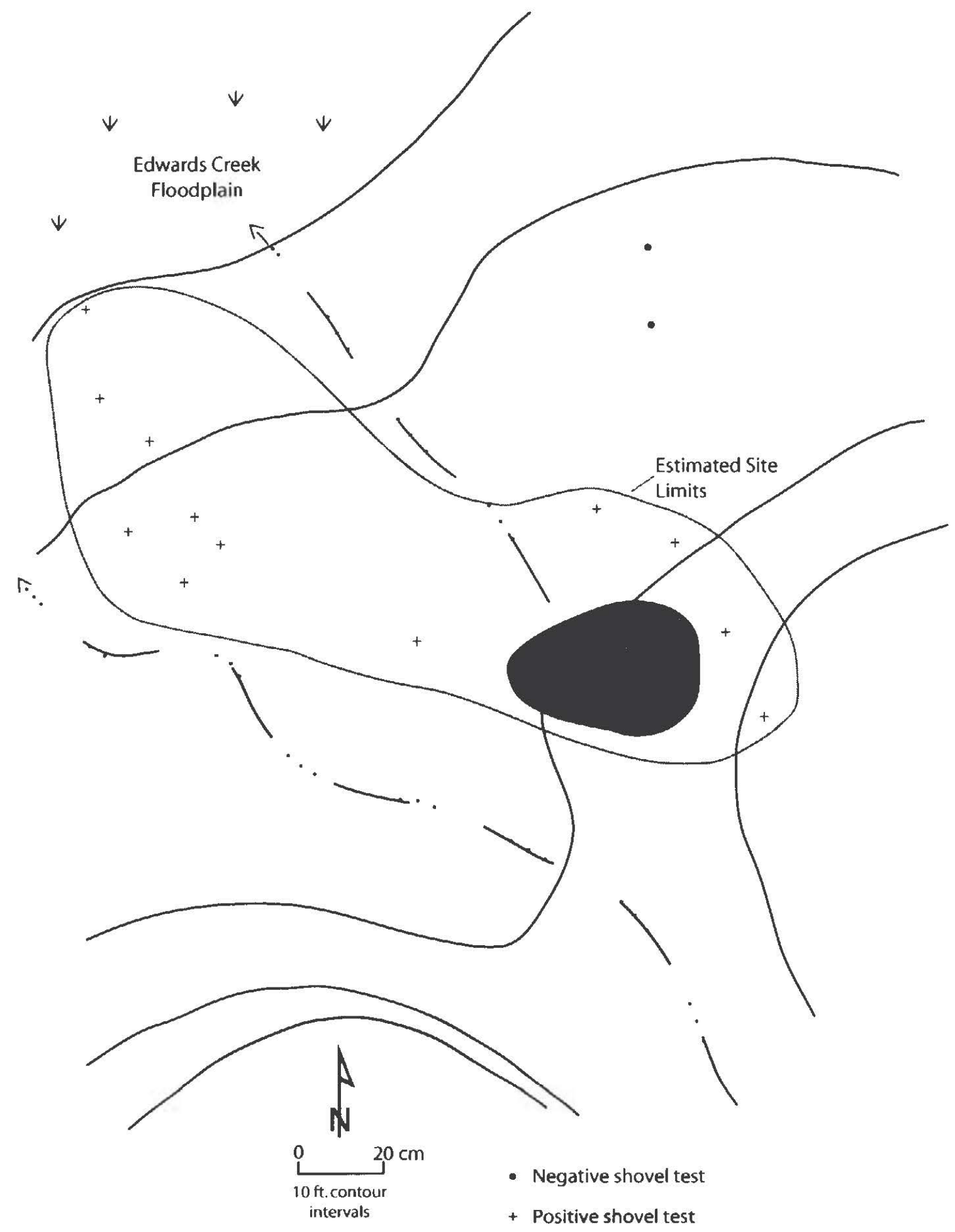

Figure 3. Distribution of $19^{\text {th }}$ century historic artifacts at the Edwards Creek site. 


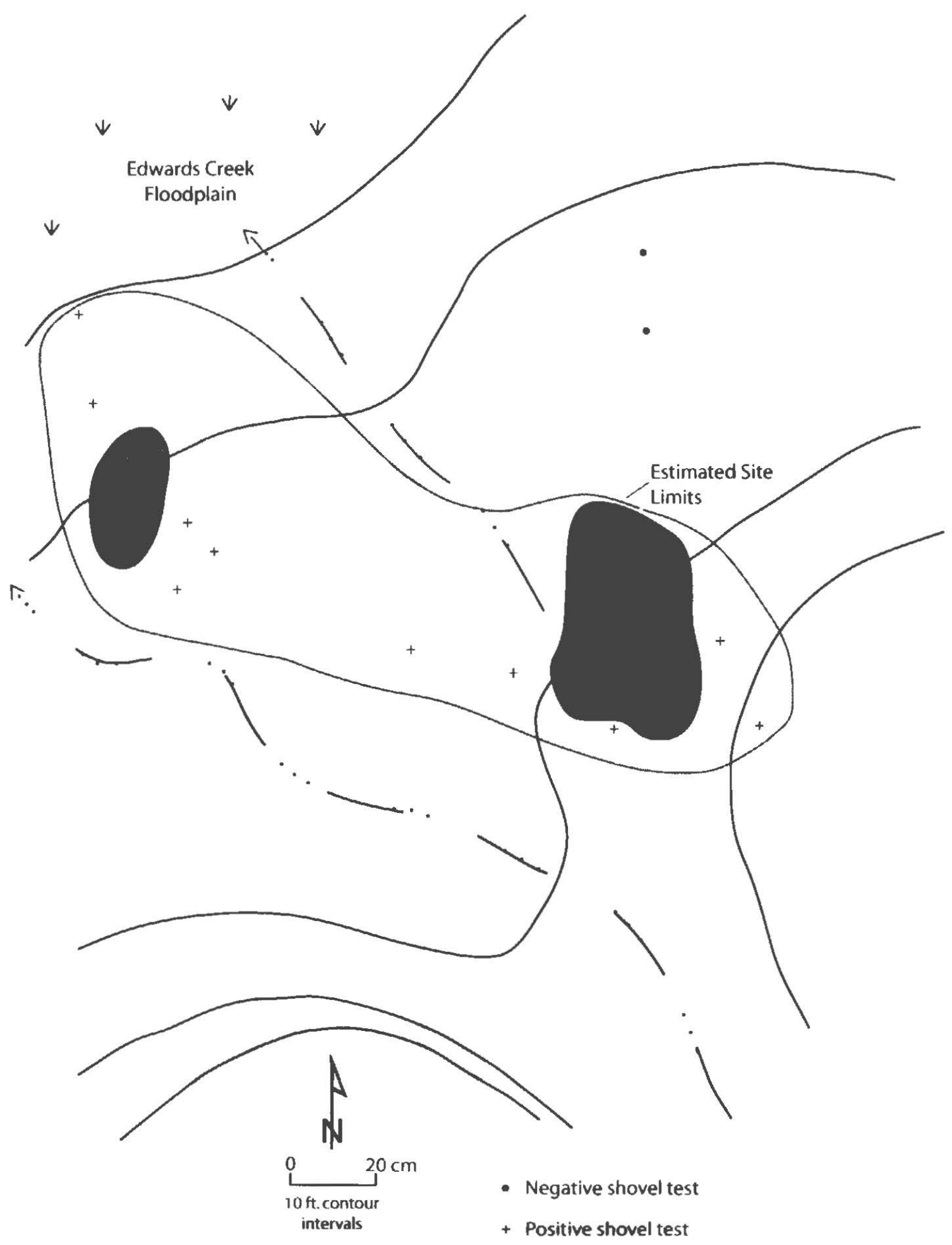

Figure 4. Concentrations of lithic artifacts at the Edwards Creek site. 


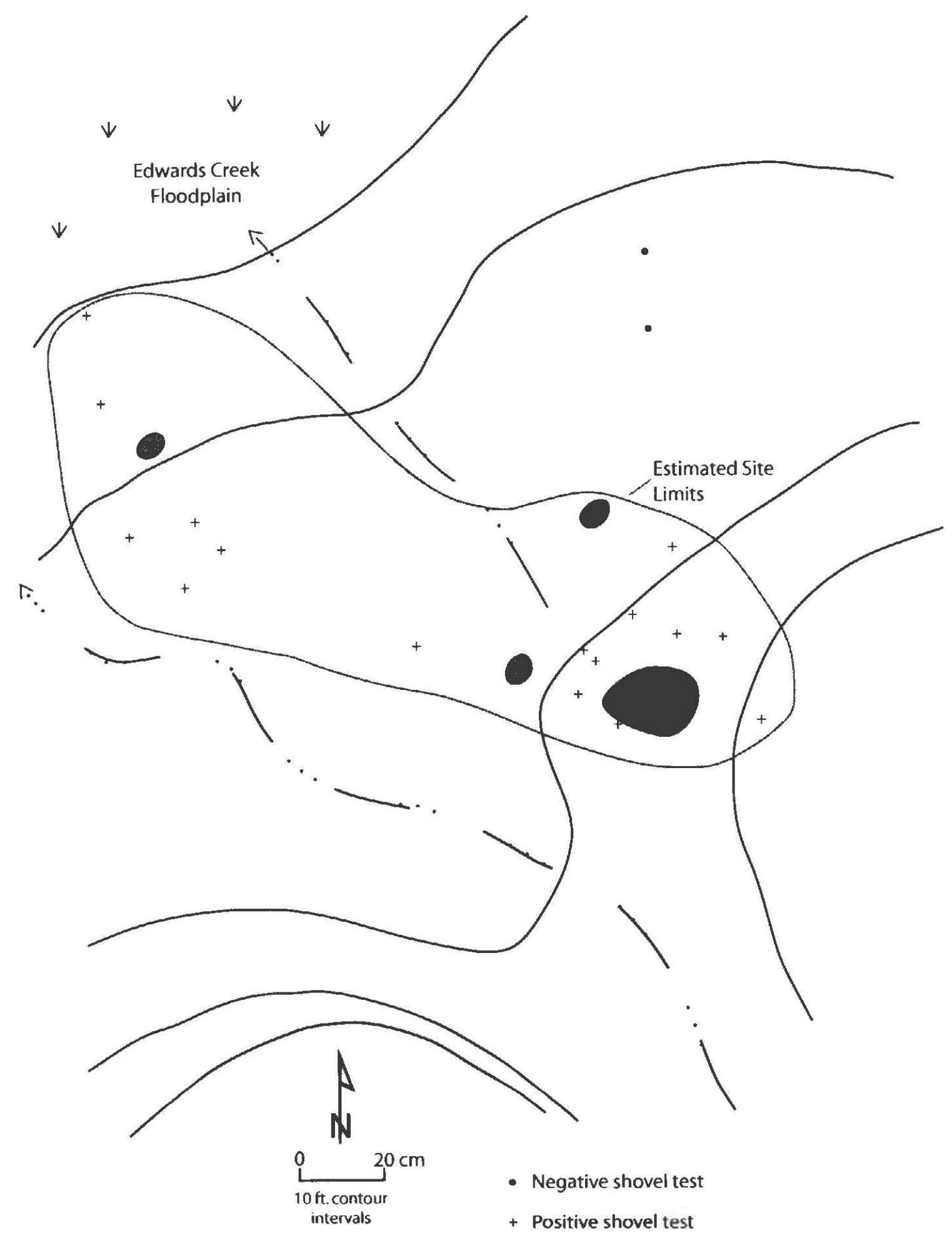

Figure 5. Distribution of aboriginal Caddo sherds at the Edwards Creek site. 
The artifacts found in the midden can be interpreted in several ways. First, a possibility is that the midden gradually accumulated over several centuries, with its initial use taking place in prehistoric times (as possibly marked by the Caddo sherds, lithic debris, and stone tools, see Table 3), followed several hundred years later by an early $19^{\text {th }}$ century occupation that added archeological materials to the midden deposit. Given the pervasiveness of early $19^{\text {th }}$ century artifacts from the top to the bottom of the midden, the likely historic hearth feature in ST 17, and the recovery of pig bones throughout the midden deposits (see Schniebs, below), the first scenario seems unlikely. A second possibility is that the midden deposits were rapidly created during an intensive early $19^{\text {th }}$ century occupation. The aboriginal lithic and ceramic artifacts may thus be incidental inclusions in the historic midden from an earlier prehistoric occupation at this location on the toe slope. The distribution of historic artifacts, pig bones, and the ST 17 feature at the Edwards Creek site are consistent with the hypothesis that the midden deposits are a product of an early $19^{\text {th }}$ century occupation, although whether that occupation was by early Anglo-American settlers or Caddo peoples is not clear on the basis of the recovered historic artifacts. The third scenario is that the midden was deposited in the early $19^{\text {th }}$ century by aboriginal Caddo peoples that had access to European-manufactured goods but continued to employ traditional ceramic and lithic technologies to some extent during this occupation. This is the most intriguing possibility because Caddo sites occupied during this period (i.e., around the time of their 1835 land cession in Louisiana, and the forced removal of the Caddo from East Texas, see Smith 2005) and is one worth further consideration. But first, the aboriginal and historic European artifacts recovered from the Edwards Creek site will be discussed, followed by the analysis of the animal bone found in the investigations.

\section{Aboriginal Artifacts}

There are 11 grog-tempered Caddo sherds in the Edwards Creek site collection, three from the surface of the midden, four from shovel tests in the midden (see Table 3), and four from shovel tests northwest and west of the midden (see Figures 2 and 5). Eight of these sherds are plain body sherds, and three are from decorated portions of utility ware vessels.

The first decorated sherd is a rim from an everted rim jar with rows of tool punctates and fingernail punctates (Figure 6a). A second is a body sherd that has rows of fingernail punctates that cover the entire sherd surface (Figure $6 \mathrm{c}$ ). Both of these decorated sherds are from shovel tests in the midden, and came from 40 $80 \mathrm{~cm}$ bs. The third decorated sherd is an incised body sherd from ST $8(20-40 \mathrm{~cm}$ bs). It has parallel and cross-hatched incised lines on it (Figure 6b). 


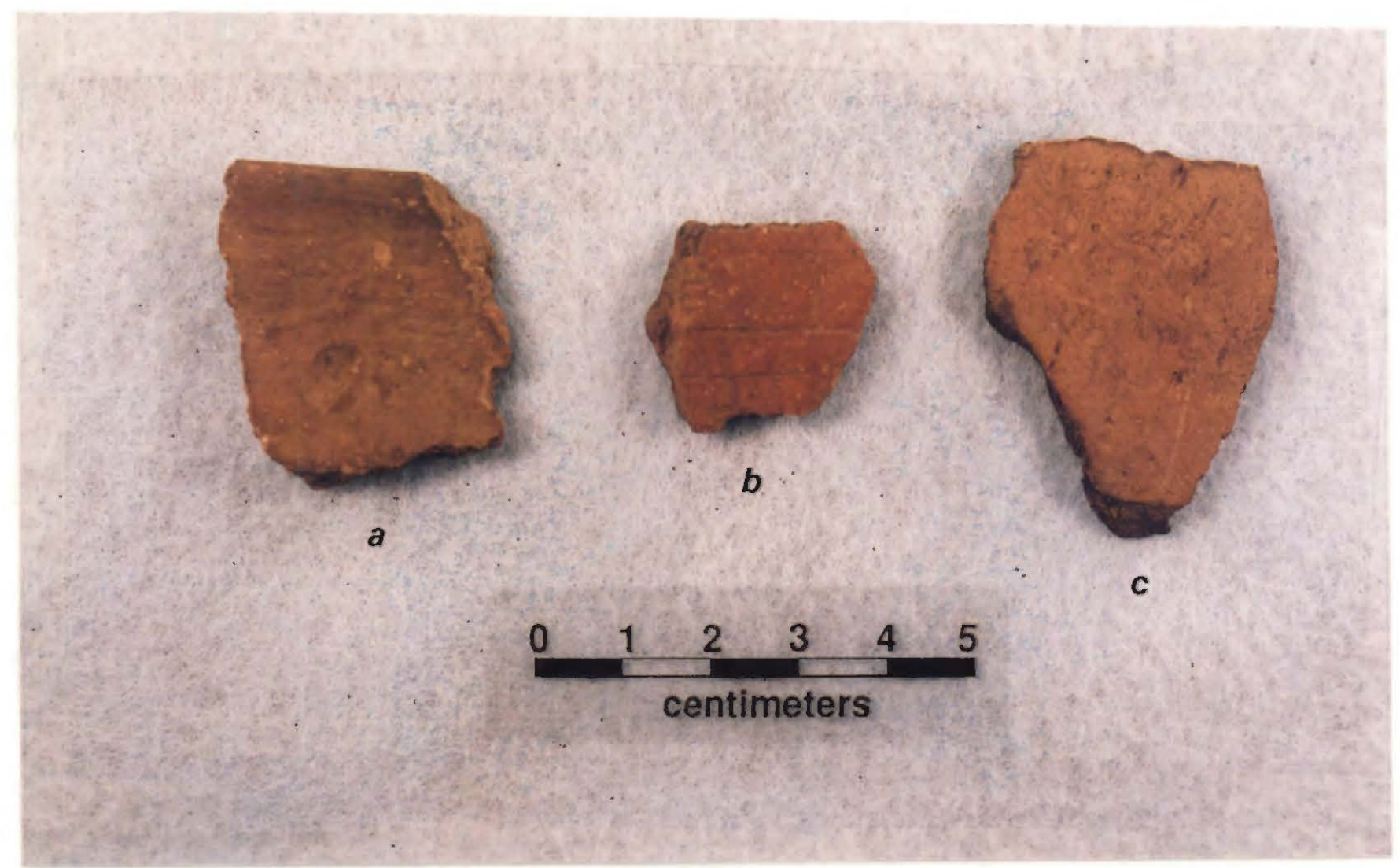

Figure 6. Decorated Caddo sherds: $a$, tool-fingernail punctated rim; $b$, parallel and crosshatched incised; c, fingernail punctated. Provenience: a, ST 22, 60-80 cm; b, ST 8, 20-40 $\mathrm{cm} ; \mathrm{c}$, ST 3, 40-60 cm.

Chipped stone tools from the Edwards Creek site include three dart points or dart point fragments, two arrow points, three expedient flake tools, and a biface fragment. Surface finds include two of the dart points, one arrow point, and one flake tool; this latter tool was found on the surface of the midden.

The dart points are Gary, var. Camden examples (Figure 7c-d). Both are made from a local coarse-grained quartzite. These points are thin $(6.1-6.5 \mathrm{~mm})$ and relatively narrow stemmed $(13.0-14.7 \mathrm{~mm})$ contracting stem dart points with resharpened blades. The var. Camden dart points were made and used in the latter part of the Woodland period, between ca. A.D. 200-700 (see Schambach 1982). One of these points is from the surface (see Figure 7d) and the other is from ST 8 $(0-20 \mathrm{~cm})$, north-northwest of the midden deposits (see Figures 2 and 4). 


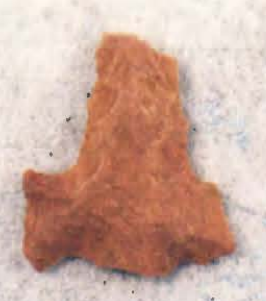

a

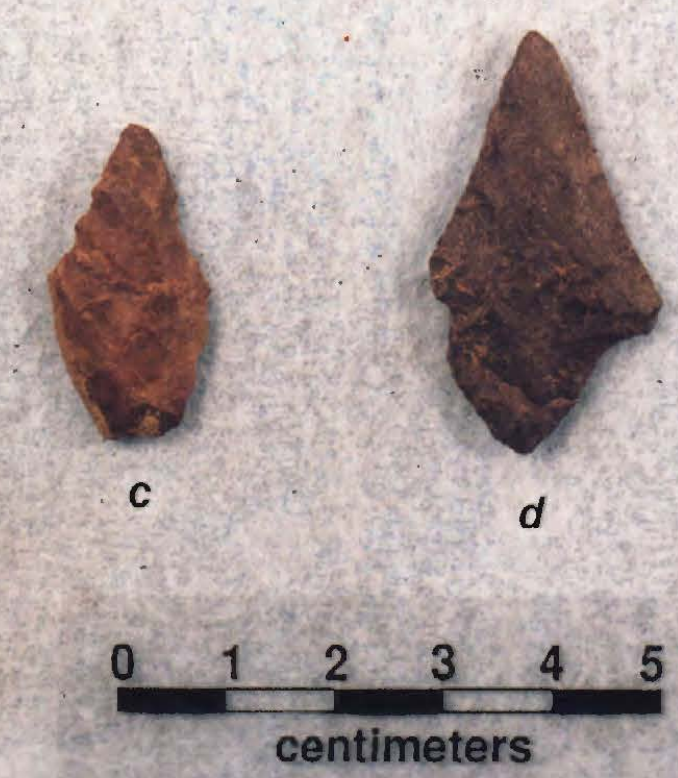

Figure 7. Projectile points from the Edwards Creek site: a, Catahoula arrow point; $b$, Perdiz arrow point; c-d, Gary dart points. Provenience: a, d, Surface; b, ST 12, 60-70 cm; c, ST 8, 0-20 cm.

A quartzite Catahoula arrow point (see Figure 7a) was also found on the surface in a gopher mound. A Perdiz, made of a light yellow chert (see Figure 7b), was recovered from deep in the midden (ST 12, 60-70 cm bs). Previous archaeological studies of prehistoric Caddo sites in northeastern Texas, and contemporaneous Late Prehistoric sites in the middle Trinity River basin (cf. McGregor and Bruseth 1987), suggest that Catahoula points were made and used between ca. A.D. 900-1300 and Perdiz points were made after ca. A.D. 1300. These distinctive narrow contracting stem arrow points have been found as late as $18^{\text {th }}$ century archaeological contexts on historic Caddo sites, but when such arrow points were no longer being made is not known.

Two of the flake tools have unilateral use wear (ST 5, 0-20 cm bs and ST $10,20-40 \mathrm{~cm}$ bs, both shovel tests west of the midden, see Figures 2 and 4), while the third (from the surface of the midden) is an expedient scraping tool with distal and lateral retouch and use wear. The three flake tools are made on gray chert.

Lithic debris from chipped stone tool manufacture was present on the surface of the midden, in the midden itself (see Table 3 ), and in a number of 
shovel tests across the site (see Table 2 and Figures 2 and 4). There are no cores in the small assemblage.

From surface contexts, the lithic debris derives from nine different raw materials - probably all available in Trinity River floodplain and upland gravel sources-particularly quartzite $(28.1 \%)$, gray chert $(25.0 \%)$, and dark gray chert $(12.5 \%)$. Less common lithic raw materials in the debris found on the midden surface include light gray chert $(9.4 \%)$, red chert $(6.2 \%)$, petrified wood $(6.2 \%)$, grayish-black chert $(6.2 \%)$, brown chert $(3.1 \%)$, and a grayish-brown chert $(3.1 \%)$. The lithic debris recovered from the shovel testing is dominated by gray chert $(41.5 \%)$, light gray chert $(16.9 \%)$, and quartzite $(15.4 \%)$. Other cherts represented in the shovel test lithic debris are brown $(6.2 \%)$, dark gray $(7.7 \%)$, grayish-brown $(4.6 \%)$, and red $(3.1 \%)$ colors. Other materials include petrified wood $(1.5 \%)$ and ferruginous sandstone $(1.5 \%)$. Only one piece of novaculite (from Red River gravels or the Ouachita Mountains) is from an obvious non-local lithic raw material source.

The lithic debris from the Edwards Creek site may be a product of the knapping of chipped stone tools in prehistoric times. The dart points and arrow points found with the lithic debris would seem to indicate that this is the case, although these points could be indicative of nothing more than the later re-use or scavenging of lithic materials; this seems unlikely given the relative abundance of lithic raw material sources in the middle Trinity River basin. Nevertheless, it is also apparently a fact that the Caddo continued to manufacture chipped stone tools as late as the $1830 \mathrm{~s}$. At the ca. $1800-1830$ s Timber Hill site in Marion County, Texas, for example, the Caddo "may still have been collecting and using lithic materials to make simple scraping and cutting tools" (Parsons et al. 2002:41). Although not a Caddo site, Brooks (2007:4) reports that lithic debris, modified flakes, knives, scrapers, and a stemmed arrow point were recovered from a late $1830 \mathrm{~s}-\mathrm{mid}-1840$ s Choctaw site in eastern Oklahoma, where a chipped stone technology was still a part of more traditional Choctaw material culture.

\section{Historic European Artifacts}

Refined earthenwares are the most common $19^{\text {th }}$ century historic artifacts from the Edwards Creek site, all from midden contexts (see Figures 2 and 3 and Tables 1 and 3). The refined earthenwares include both pearlware and whitewares (cf. Majewski and O'Brien 1987), although they could not be consistently differentiated because of the small size of many of the sherds found at the site.

Seventeen of the refined earthenware sherds are plain. Two others are annular ware (with black or blue bands), three are transfer-printed (one black and two dark blue printed), one is a mocha ware sherd, and two are hand-painted (dark blue and green colors) with floral motifs. There are also two blue shell-edged plate rim sherds (Figure 8c-d). All of these decorated refined earthenwares are 
probably of English manufacture, and as an assemblage may date conservatively from ca. $1820 / 1830$ to 1860 .

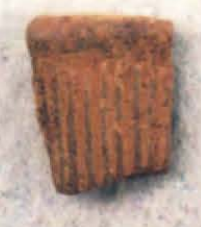

a

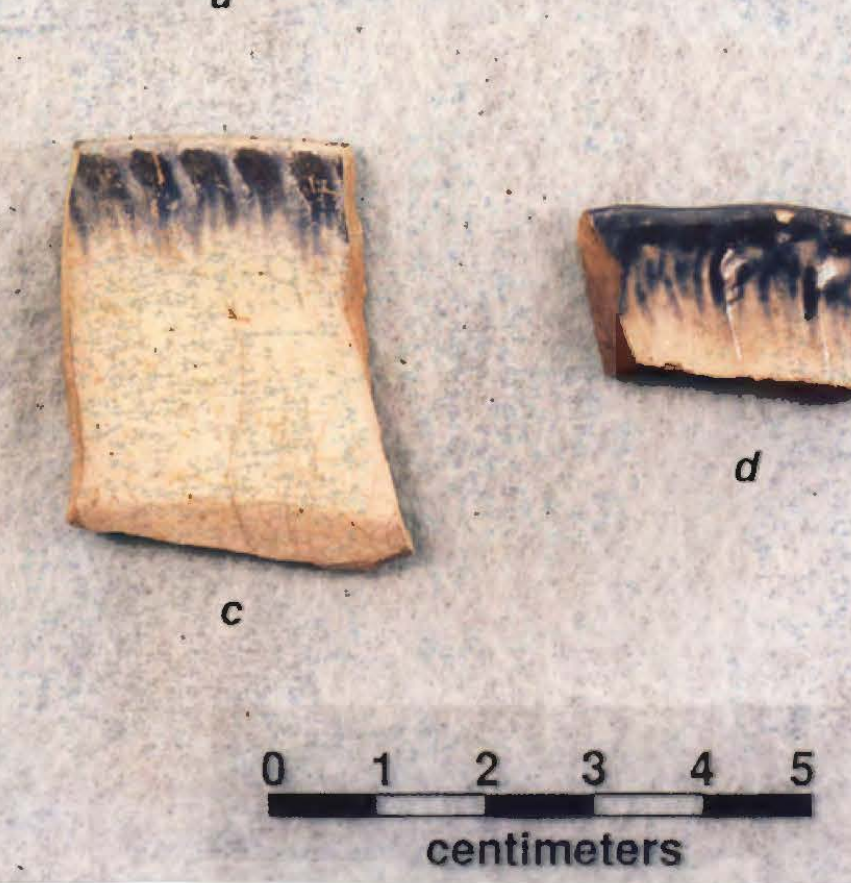

Figure 8. Selected historic artifacts from the Edwards Creek site: a, stoneware pipe sherd; b, bone button; c-d, blue shell-edged rim sherds. Provenience: a, ST 5, 20-40 cm; b, ST 3 , $40-60 \mathrm{~cm}$; c, Surface; d, ST 3, 40-60 cm.

The mean beginning and end production date ranges for the black and dark blue colors used on transfer-printed earthenwares, following Samford (1997: Table 5), are 1825-1838 and 1819-1835, respectively. More specific chronological data on the refined earthenwares also comes from the shell-edged plates. One of the shell-edged rims is unscalloped with straight impressed lines on it (see Figure 8c). Miller and Hunter (1990, 1994) suggest vessels with this rim treatment were manufactured between ca. 1830-1860. The other blue shell-edged plate rim (see Figure 8d) is even scalloped, with straight impressed lines. This variety of shell-edged plate apparently dates from ca. 1810-1835 (Miller and Hunter 1990: Figure 17, 1994: Plate V). Miller and Hunter (1990: Table 2) indicate that the popularity of shell-edged tableware in American markets peaked between 1824-1830.

One yellow ware sherd came from above the midden in ST $15(0-20 \mathrm{~cm}$ bs). Yellow ware vessels began to be produced in the late 1820 s in England, but 
by the 1840s it was being manufactured in the United States (Leibowitz 1985:4). The peak production of yellow ware was in the 1860 s and 1870s.

There are nine cut nails among the historic artifacts, six from shovel tests in the midden, one from the surface of the midden, and two from shovel tests (ST 7 and 20) just west of the midden (see Figures 2 and 3). Such nails were manufactured between ca. 1820-1891 (Wells 2000: Figure 8). Their presence at the Edwards Creek site suggests that a structure stood in the area of the midden that was built at least in part through the use of cut nails; not of the nails have been modified or reworked in any manner.

Eight pieces of bottle glass are in the artifact collection from the site, including olive-green $(n=3)$, aqua $(n=3)$, and clear or colorless $(n=2)$ bottle glass sherds. These sherds are probably from bottles that held patent medicines, wine, whiskey, or brandy. Such glass bottles were likely made between ca. 1830-1850, or possibly later; however, none of the bottle glass sherds have embossed lettering, which began to be used about 1850 (Newman 1970:74).

One ribbed stoneware pipe rim sherd came from ST $5(20-40 \mathrm{~cm})$ from near the midden deposits (see Figure 8a, see also Figures 2 and 3). The pipe sherd is probably from an elbow-shaped reed stem pipe that had a replaceable wooden reed stem. Similar reed stem pipes have been documented from ca. 1837-1846 (Nelson and Perttula 2003: Figure 11) and ca. 1852-1857 (Perttula 1989:98) farmsteads in northeastern Texas.

There is one fragmentary bone button from the midden (see Figure 8b). It is ribbed, and apparently had four centrally placed holes. This may be a commercially manufactured button type.

\section{EDWARDS CREEK SITE FAUNAL ANALYSIS}

\section{LeeAnna Schniebs}

\section{Introduction}

Investigations at the Edwards Creek site (41FT549) in Freestone County, Texas, yielded 102 faunal specimens, and total weight of the sample is 191.05 grams. Faunal material was recovered from 11 shovel tests in and around the midden (Figure 9), covering an area of approximately 1520 square meters, with depths ranging from 0-100 centimeters below surface ( $\mathrm{cm} \mathrm{bs)}$.

The fauna from this site is likely the subsistence debris of both aboriginal (possibly dating as early as ca. A.D. 1300) and early historic (ca. 1820-1860) occupations, although it is possible that it may all be a product of the latter occupation. The purpose of the faunal analysis is to document subsistence patterns 
during aboriginal times and during the contact period of native Caddo and early settlers in the area, including the utilization of available natural resources and as well as the use of domestic livestock. The following report discusses the methods employed in the faunal analysis and results of taxonomic identification and quantification of the faunal assemblage.

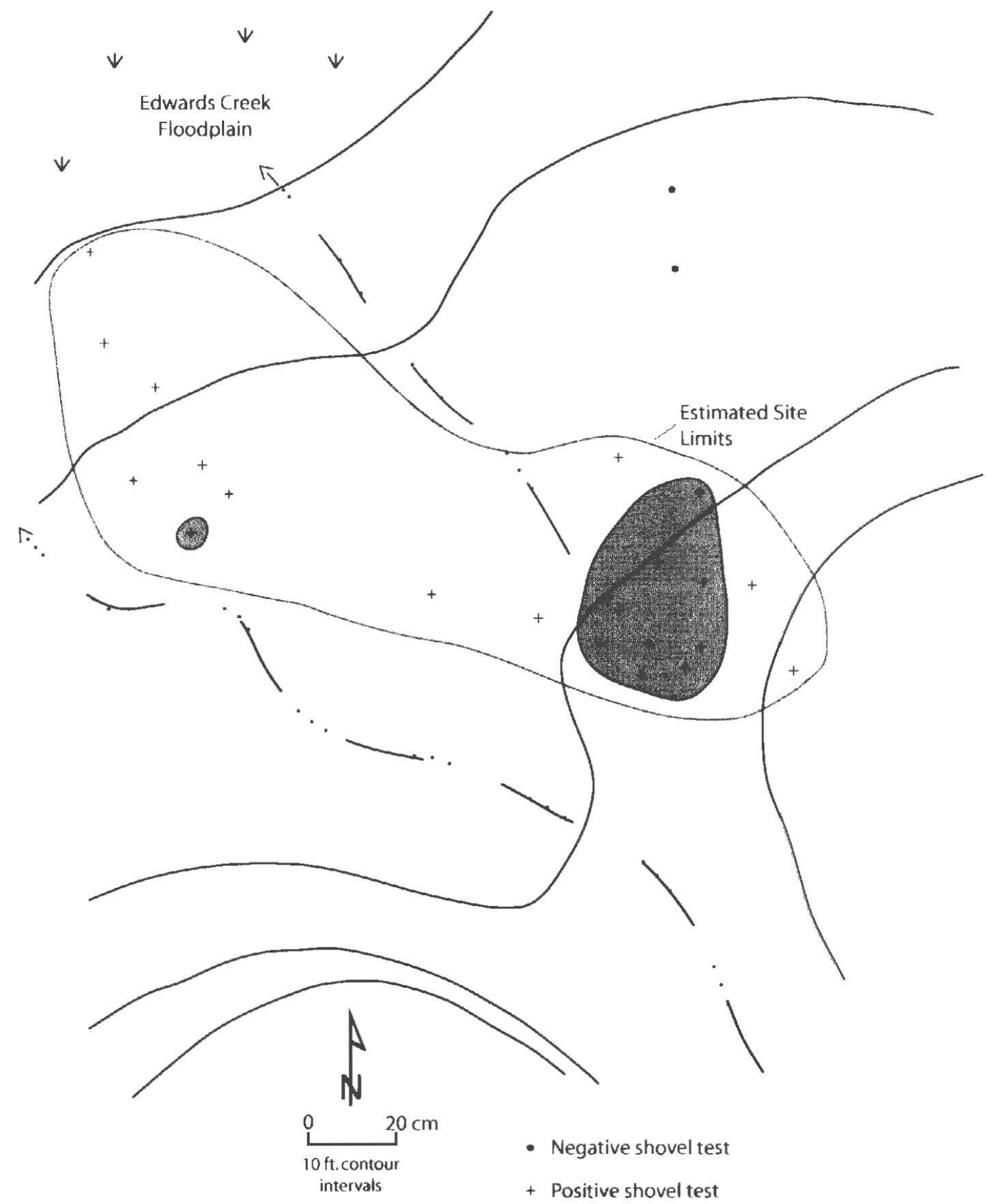

Figure 9. Distribution of animal bone at the Edwards Creek site. 


\section{Methodology}

All vertebrate remains were inventoried and weighed. Excel 5.0 was used to manipulate the generated data. An Ohaus digital scale, Model CT600-S, was used to record bone weight. Identifications were made to the most specific category possible depending on the condition of the bone and available comparative material.

Standard zooarchaeological methods have been used. Both unidentifiable and identifiable pieces were analyzed in similar fashion. That is, the same attributes were recorded: taxon, element and portion of that element, anatomical location of the element, condition of the bone and any notes on age, taphonomy, burning, gnawing, fracture patterns, and presence of modification, if applicable. Provenience information was also recorded.

Quantification of the assemblage is summarized as number of identified specimens per taxon (NISP) and as minimum number of individuals (MNI) for identified elements. MNI estimates were calculated according to the most frequently occurring element, based on symmetry and element portion (Munzel 1986). In most cases, the presence of a single element constituted an MNI of one. The minimum numbers method was chosen as the most suitable analytical measure of abundance. "It involves no hypotheses and is purely factual. The minimum number of animals that the bones could have come from is an indisputable fact" (Chaplin I97 I:69-70). The fragments method and the weights method to quantify results require too many assumptions as to processing techniques and post-mortem and/or post-depositional preservation.

The faunal data tables in this section are standard species lists with the number of occurrences for each animal. Those specimens regarded as unidentifiable (those coded to only class) have been consolidated into a few general categories. Elements of non-diagnostic skeletal value (unidentifiable fragments, ribs, vertebrae, and long bone shafts; see Olsen 1964), are coded in an indeterminate category by class and size range. For example, specimens counted as small mammal is rabbit-size, large mammal refers to a deer-size mammal, and a very large mammal is cow/bison-size. Indeterminate vertebrate includes the bones of unidentifiable class. Recording these specimens in a size category enables the most precise level of observation as the specimen allows. In small samples, taking note of weight and the size categories of non-diagnostic elements broadens the function of the bone assemblage. However, percentages referred to in this report are calculated by number of bones (NISP) rather than weight. The complete inventory of the Edwards Creek site faunal collection can be found in Table 4. 
Table 4. Inventory of Edwards Creek site (41FT549) faunal assemblage.

\begin{tabular}{|c|c|c|c|c|c|c|c|c|c|c|c|c|}
\hline Sh Test & Depth $(\mathrm{cm})$ & Qty & Taxon & Elem/Por & Side & Age & Taphonom & Bum & Gnew & Mod & Wt/g & Comments \\
\hline 1 & 40to60 & 3 & lg mam. & unid & & & absent & blk & & & 1.1 & \\
\hline 1. & 40 to 60 & 6 & sm mam & I.b. frag & & & exfol & not & & & 0.6 & \\
\hline 1 & 60 to 80 & 1 & Ig mam & unid & & & absent & blk & & & 1.3 & \\
\hline 1 & $60 t 080$ & 1 & sm mam & unid & & & absent & wh & & & 0.2 & \\
\hline 3 & 0 to 20 & 1 & deer & phx 1 prox & L & & etch & not & & & 4.1 & \\
\hline 3 & Oto20 & 1 & lg mam & unid & & & absent & wh & & & 1.2 & \\
\hline 3 & 20 to 40 & 1 & Ig mam & I.b. frag & & & exfol & not & & & 0.4 & spir frac \\
\hline 3 & $20 t 040$ & 5 & Ig mam & unid & & & exfol & not & & & 1.9 & \\
\hline 3 & $60 t o 70$ & 1 & Ig mam & unid & & & absent & not & & & 0.2 & \\
\hline 5 & Oto20 & 1. & deer & tib shft frg & & & exfol & not & rodent & & 3.1 & spir frac \\
\hline 5 & 20 to 40 & 1 & Ig mam & unid & & & absent & not & & & 0.05 & \\
\hline 6 & 20 to 40 & 4 & v. Ig mam & I.b. frag & & & exfol & not & & & 18.2 & spir frac \\
\hline 7 & Oto20 & 2 & deer & podial frg & & & absent & wh & & & 0.9 & \\
\hline 7 & 40 to 60 & 1 & lg mam & I.b. frag & & & absent & not & rodent & & 0.5 & spir frac \\
\hline 7 & 40 to60 & 2 & Ig mam & unid & & & absent & not & & & 0.7 & \\
\hline 7 & 40 to 60 & 1 & turtle & shell frg & & & absent & not & & & 0.1 & \\
\hline 10 & 20 to 40 & 1 & lg mam & unid & & & exfol & not & & & 1.2 & \\
\hline 12 & $20 t 040$ & 1 & Ig mam & l.b. frag & & & exfol & not & & & 0.5 & \\
\hline 12 & 20 to 40 & 1 & lg mam & unid & & & absent & blk & & & 0.3 & \\
\hline 12 & 20 to 40 & 1 & Ig mam & unid & & & absent & not & & & 0.2 & \\
\hline 12 & 20 to 40 & 1 & v. Ig mam & I.b. frag & & & exfol & not & & & 2.1 & spir frac \\
\hline 15 & Oto20 & 1 & Ig mam & l.b. frag & & & exfol & not & & & 1 & \\
\hline 17 & 80 & 1 & deer & fem & $\mathbf{R}$ & imm & etch,exfol & not & & & 80.4 & no epiph \\
\hline 17 & $20 t 040$ & 1 & Ig mam & unid & & & exfol & not & & & 0.3 & \\
\hline 17 & 20 to 40 & 1 & v. lg mam & rad shft frg & & & absent & blk & & & 1.2 & \\
\hline 17 & 40 to60 & 1 & softshell tur & r shell frg & & & absent & char & & & 2.4 & v. Ig indiv \\
\hline 17. & $40 t 060$ & 1 & unid & unid & & & exfol & wh & & & 0.1 & \\
\hline 17 & 60 to 80 & 4 & Ig mam & unid & & & absent & not & & & 1.2 & \\
\hline 17 & 60 to 80 & 2 & Ig mam & unid & & & exfol & not & & & 1.1 & \\
\hline 17 & 60 to 80 & 3 & lg mam & unid & & & absent & wh & & & 2.7 & \\
\hline 17 & $60 t o 80$ & 1 & pig & tusk frg & & & absent & not & & & 0.3 & \\
\hline 17 & $60 t o 80$ & 1 & sm mam & unid & & & absent & wh & & & 0.1 & \\
\hline 17 & 80 to 85 & 1 & lg mam & bulla frg & & & absent & not & & & 5.4 & not deer? \\
\hline 17 & 80 to 85 & 1 & lg mam & unid & & & absent & not & & & 0.2 & \\
\hline 17 & 80 to 85 & 3 & lg mam & unid & & & absent & wh & & & 1.3 & \\
\hline 17 & 80 to 85 & 1 & sm mam & I.b. frag & & & absent & wh & & & 0.3 & \\
\hline 17 & 80 to85 & 1 & sm mam & unid & & & absent & wh & & & 0.05 & \\
\hline 17 & 80 to85 & 1 & v. lg mam & rib frg & & & etch & not & & & 18 & spir frac \\
\hline 22 & Oto20 & 1 & lg mam & unid & & & exfol & not & & & 0.4 & \\
\hline 22 & 20 to 40 & 1 & lg mam & l.b. frag & & & absent & not & & & 0.8 & spir frac \\
\hline 22 & $20 t 040$ & 1. & sm mam & unid & & & absent & wh & & & 0.1 & \\
\hline 22 & $40 t 060$ & 1. & deer & ulnar notch L & $L$ & & absent & not & carn & & 15.3 & \\
\hline 22 & $40 t 060$ & 11 & lg mam & unid & & & exfol & not & & & 0.2 & \\
\hline 22 & $60 t o 80$ & 111 & Ig mam & unid & & & absent & not & & & 2 & poss rib frgs \\
\hline 22 & $60 t o 80$ & 11 & lg mam & scap frg & & & absent & not & & & 3.1 & \\
\hline 22 & 60 to 80 & 11 & Ig mam & fem head frg & & & absent & char & & & 5.5 & \\
\hline 22 & 60 to 80 & $7 !$ & lg mam & unid & & & absent & wh & & & 1.5 & \\
\hline 22 & 80 to 100 & 11 & lg mam & unid & & & absent & wh & & & 0.4 & \\
\hline 24 & 20 to 40 & 1 & pig & tooth frg & & & absent & not & & & 2.2 & cheek tooth \\
\hline midden & gen coll(suri & 11 & box turtle & shell frg & & & absent & not & & & 0.2 & \\
\hline midden & gen coll(suri & 1 & deer & phx 3 prox L & L & & absent & wh & & & 0.9 & \\
\hline midden & gen coll(sur & 11 & Ig mam & tooth frg & & & absent & not & & & 0.1 & \\
\hline midden & gen coll(surt & 3 & Ig mam & unid & & & absent & not & & & 0.9 & \\
\hline midden & gen coll(sur) & 11 & Ig marn & unid & & & absent & wh & & & 0.3 & \\
\hline midden & gen coll(sur) & 4 r & med fish & unid & & & absent & not & & & 1.6 & \\
\hline midden & gen collisur & 1 & pig & tooth frg & & & absent & not & & & 0.6 & \\
\hline midden & gen coll(surt & $1:$ & sm mam & unid & & & absent & wh & & & 0.05 & \\
\hline
\end{tabular}




\section{Results}

The following section describes the preferred habitat for all of the identifiable vertebrate taxa recovered from the Edwards Creek site midden. Taxonomic classes identified include fish, reptile, and mammal. Number of identified specimens (NISP) and minimum number of individuals (MNI) for each taxon are summarized in Table 5, as are weights for each taxon and approximate percentages of the assemblage. Composition of the anatomical elements for each taxon can be found in Table 6 .

\section{Table 5. Taxonomic composition of the faunal assemblage.}

\begin{tabular}{|l|l|r|r|r|r|}
\hline Scientific Name & Common Name & NISP & MNI & \% of Sample & Wt/g \\
\hline Vertebrata (indeterminate) & unidentifiable & 1 & & 1 & 0.1 \\
\hline Osteichthyes & med. fish & 4 & 1 & 4 & 1.6 \\
Testudinata & turtle & 1 & & 1 & 0.1 \\
\hline Terrapene sp. & box turtle & 1 & 1 & 1 & 0.2 \\
Trionyx sp. & softshell turtle & 1 & 1 & 1 & 2.4 \\
\hline Mammalia (small) & sm. mammal & 12 & 1 & 11 & 1.4 \\
\hline Mammalia (large) & Ig. mammal & 65 & & 64 & 37.95 \\
\hline Mammalia (very large) & very lg. mammal & 7 & & 7 & 39.5 \\
\hline Sus scrofa & pig & 3 & 1 & 3 & 3.1 \\
\hline Odocoileus sp. & deer & 7 & 1 & 7 & 104.7 \\
\hline & TOTAL & 102 & & 100 & 191.05 \\
\hline
\end{tabular}




\section{Table 6. Composition of faunal elements.}

\begin{tabular}{|c|c|c|c|c|c|c|c|c|}
\hline \multirow[t]{2}{*}{ Scientific Name } & \multirow[t]{2}{*}{ Common Name } & \multicolumn{2}{|c|}{ Element } & \multirow[b]{2}{*}{ tooth } & \multirow[b]{2}{*}{ axial } & \multirow[b]{2}{*}{ long bone } & \multirow[b]{2}{*}{ podial/phx } & \multirow[b]{2}{*}{ other } \\
\hline & & unid & cranial & & & & & \\
\hline Vertebrata (indeterminate) & unidentifiable & 1 & & & & & & \\
\hline Osteichthyes & med. fish & 4 & & & & & & \\
\hline Testudinata & turtle & & & & & & & 1 \\
\hline Terrapene sp. & box turtle & & & & & & & 1 \\
\hline Trionyx $s p$ & softshell turtle & & & & & & & 1 \\
\hline Mammalia (small) & sm. mammal & 5 & & & & 7 & & \\
\hline Mammalia (large) & Ig. mammal & 56 & 1 & 1 & 1 & 6 & & \\
\hline Mammalia (very large) & very lg. mammal & & & & 1 & 6 & & \\
\hline Sus scrofa & pig & & & 3 & & & & \\
\hline \multirow[t]{2}{*}{ Odocoileus sp. } & deer & & & & & 3 & 4 & \\
\hline & TOTAL & 66 & 1 & 4 & 2 & 22 & 4 & 3 \\
\hline \multirow{2}{*}{\multicolumn{9}{|c|}{ NOTE: }} \\
\hline & & & & & & & & \\
\hline \multicolumn{9}{|l|}{ "Cranial" = one bulla fragment. } \\
\hline \multicolumn{9}{|c|}{ "Tooth" = fragments only. } \\
\hline \multicolumn{9}{|c|}{ "Axial" = rib and scapula fragments. } \\
\hline \multicolumn{9}{|c|}{ "Long Bone" = fragments and one complete femur without epiphysis. } \\
\hline \multicolumn{9}{|c|}{ "Podial/Phx" = two foot bone fragments and two toe bones. } \\
\hline "Other" = shell fragments. & & & & & & & & \\
\hline
\end{tabular}

Class Osteichthyes

Order and Family indeterminate

Four small fragments from unidentifiable medium-size fish were recovered from general collection in the midden. Absence of diagnostic attributes prevented specific identification. None of theses pieces are burned. The presence of fish remains in the collection is not unusual, especially given the location of the site on Edwards Creek, on the west side of the Trinity River valley. The site occupants undoubtedly took advantage of the water's resources.

Fish were used extensively by the Caddo Indians, with no known limitations on variety or size (Newcomb 1993). They were caught in several ways, including trotlines: short lines were hung about a foot apart from a long line with hooks on each end baited with "dough bait" or meat. The line can be checked 
several times a day, yielding good-sized fish. The method is almost identical to the one used today.

Class Reptilia

Order Testudinata, Family Emydidae

Box turtle (Terrapene sp.) is represented by one small shell fragment recovered from general collection in the midden. The specimen is not burned. Two species occur in the project area. The three-toed box turtle ( $T$. carolina) prefers woodlands and thickets, and the Ornate box turtle ( $T$. ornata) occurs in open, treeless areas; these are dry-land turtles that close their shells tightly when danger threatens (Conant 1975). Turtles are dietary supplements often found in archaeological contexts.

\section{Order Testudinata, Family Trionychidae}

Softshell turtle (Trionyx sp.) is represented by one shell fragment. It was found in ST 17 between $40-60 \mathrm{~cm}$ bs. The specimen is charred, and it is noted in the comments that it is from a very large individual. Two species currently occupy the project area: the Texas Spiny Softshell (T. s. emoryi) and the Midland Spiny Softshell $(T, m$. muticus). All species are aquatic, and the preferred habitat includes small marshy creeks, farm ponds, and large, fast-flowing rivers and lakes (Behler 1995). They are powerful swimmers, and they can run on land with startling speed and agility (Conant 1975). The carapace is circular, and covered with soft, leathery skin instead of horny scutes. They have long necks, strong jaws, and sharp beaks.

\section{Order Artiodactyla, Family Suidae}

Pig (Sus scrofa) is represented by three tooth fragments. They were recovered from ST $17(60-80 \mathrm{~cm}$ bs), ST $24(20-40 \mathrm{~cm}$ bs $)$, and general collection in the midden. The fragments are not burned. These are probably the remains of domestic pig rather than a feral individual, although feral pigs have established sizeable, free-ranging populations in the wooded country of eastern Texas (Davis 1978). The domestic pig is derived from the European wild boar, and is an example of a domestic animal used entirely to man's own ends. In addition, at least some of the specimens recorded as large mammal and/or very large mammal may be the remains of pig as well.

\section{Order Artiodactyla, Family Cervidae}

Deer (Odocoileus sp.) is represented by seven specimens, including the remains of one immature individual. They were recovered from six different shovel tests, and three pieces are burned. Whitetail Deer (O. virginianus) is the only species of deer that occupies the project area, found in forests, swamps, and 
open brushy areas nearby (Burt and Grossenheider 1980). They occur in all vegetal regions, but in eastern Texas they are found in larger numbers in timbered areas (Schmidly 1983). Deer is the most common large game animal preferred by the Caddo, and also one of their main subsistence animals. Prehistorically, the Caddo were adept imitators of deer, and a hunter disguised with the antlers and hide of a deer was able to approach his quarry closely, and even to attract it to himself (Newcomb 1993). In addition to this quantity, deer is probably represented in the unidentifiable large mammal category $(n=65)$. The large mammal sample consist of unidentifiable fragments, one cranial fragment, a tooth fragment, limb bone fragments, and one scapula fragment.

The seven very large mammal bones could be the remains of pig or cow, although there were no bovid elements identified in the collection.

\section{Sample Condition}

Taphonomic patterns are the result of post-depositional deterioration or weathering on the surface of the bone. Most of the assemblage $(n=72,71 \%)$ is absent of any taphonomy, but 30 pieces are exfoliated and/or root etched (Table 7). Burning can be associated with catastrophic episodes but is usually the result of trash disposal, as is probably the case here. Thirty four specimens (33\%) from the site are burned (Table 8 ), recovered from several different shovel tests in all levels.

\section{Table 7. Summary of taphonomic patterns on faunal specimens.}

\begin{tabular}{|c|c|c|c|c|c|}
\hline \multirow[t]{2}{*}{ Scientific Name } & \multirow[t]{2}{*}{ Common Name } & \multicolumn{2}{|c|}{ Type of Taphonomy } & \multirow[b]{2}{*}{ exfoliated } & \multirow[b]{2}{*}{ etch+exfol } \\
\hline & & absent & root etch & & \\
\hline Vertebrata (indeterminate) & unidentifiable & & & 1 & \\
\hline Osteichthyes & med. fish & 4 & & & \\
\hline Testudinata & turtle & 1 & & & \\
\hline Terrapene sp. & box turtle & 1 & & & \\
\hline Trionyx sp. & softshell turtle & 1 & & & \\
\hline Mammalia (small) & sm. mammal & 6 & & 6 & \\
\hline Mammalia (large) & Ig. mammal & 51 & & 14 & \\
\hline Mammalia (very large) & very lg. mammal & 1 & 1 & 5 & \\
\hline Sus scrofa & pig & 3 & & & \\
\hline \multirow[t]{2}{*}{ Odocoileus sp. } & deer & 4 & 1 & 1 & 1 \\
\hline & TOTAL & 72 & 2 & 27 & 1 \\
\hline
\end{tabular}


Table 8. Summary of burning patterns.

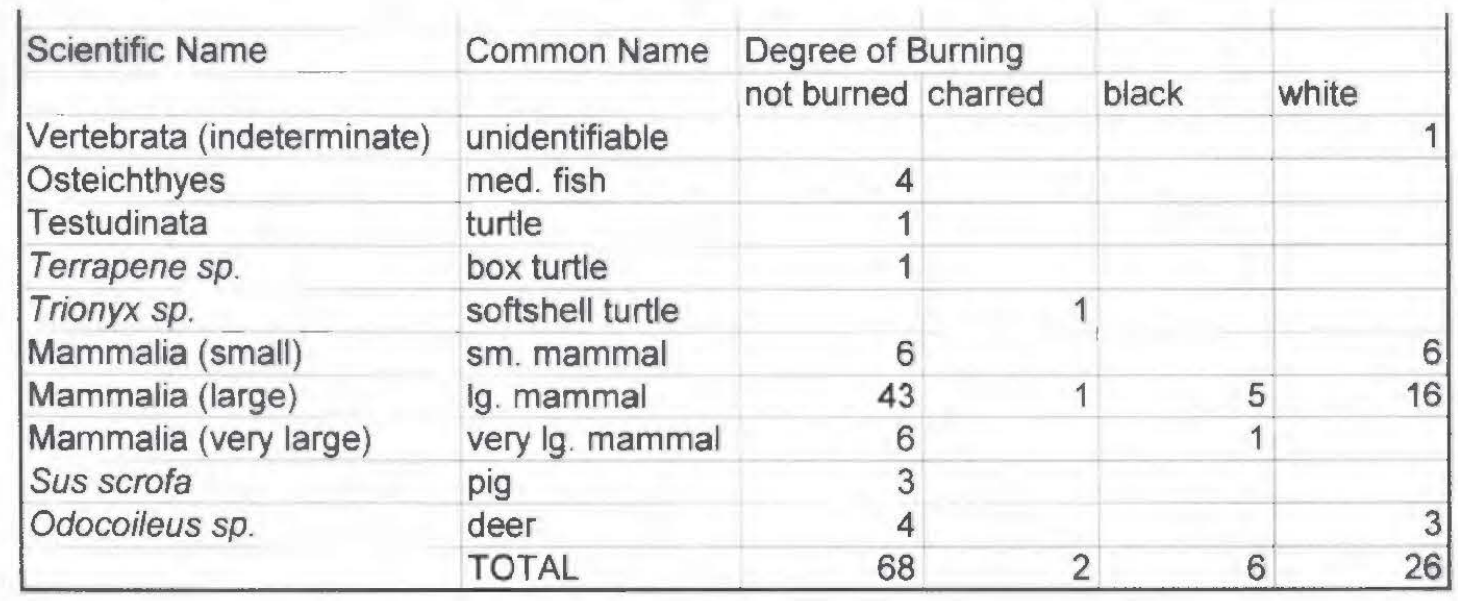

Ten fragments are spirally fractured, including six of the very large mammal bones. This is the result of impact fractures on fresh bone broken while green, rather than dry and brittle. Scavenging activities are illustrated by one carnivore gnawed piece, and rodent activity is demonstrated by two rodent gnawed fragments.

\section{Distribution}

Summaries of the horizontal and vertical distribution of the faunal remains can be found in Tables 9 and 10 (see also Figure 9). A general collection of the midden surface $(n=13)$ generated the most taxonomically diverse faunal sample, consisting of fish, box turtle, unidentifiable small and large mammal, pig, and deer. Horizontally, the largest quantity was recovered from ST 22 (one small mammal, 24 large mammal, and one deer). 
Table 9. Distribution of faunal specimens by shovel test.

\begin{tabular}{|c|c|c|c|c|c|c|c|}
\hline Provenience & Scientific Name & Common Name & \multicolumn{2}{|c|}{ Depth (cm bs) } & & & \\
\hline \multicolumn{2}{|c|}{ Shovel Test $1(\mathrm{~N}=11)$} & \multirow{3}{*}{ sm. mammal } & \multirow{2}{*}{$40 t o 60$} & \multirow{2}{*}{60 to 80} & & & \\
\hline & Mammalia (small) & & & & & & \\
\hline & Mammalia (laran) & & 6 & 1 & & & \\
\hline & Mammalıa (large) & lg. mammal & 3 & 1 & & & \\
\hline \multicolumn{2}{|c|}{ Shovel Test $3(\mathrm{~N}=9)$} & \multirow{3}{*}{$\begin{array}{l}\text { Ig. mammal } \\
\text { deer }\end{array}$} & Oto20 & 20 to 40 & 60 to 70 & & \\
\hline & Mammalia (large) & & 1 & 6 & 1 & & \\
\hline & Odocoileus sp. & & 1 & & & & \\
\hline \multirow{2}{*}{\multicolumn{2}{|c|}{ Shovel Test $5(\mathrm{~N}=2)$}} & & & & & & \\
\hline & & & Oto20 & $20 t o 40$ & & & \\
\hline & Mammalia (large) & Ig. mammal & & 1 & & & \\
\hline & Odocoileus sp. & deer & 1 & & & & \\
\hline \multirow{2}{*}{\multicolumn{2}{|c|}{ Shovel Test $6(N=4)$}} & & & & & & \\
\hline & & & $20 t 040$ & & & & \\
\hline & Mammalia (very large) & very lg. mammal & 4 & & & & \\
\hline \multicolumn{2}{|c|}{ Shovel Test $7(\mathrm{~N}=6)$} & & Oto20 & 40 to 60 & & & \\
\hline & Testudinata & turtle & & 1 & & & \\
\hline & Mammalia (large) & Ig. mammal & & 3 & & & \\
\hline & Odocoileus sp. & deer & 2. & & & & \\
\hline \multirow{2}{*}{\multicolumn{2}{|c|}{ Shovel Test $10(\mathrm{~N}=1)$}} & & & & & & \\
\hline & & & 20 to 40 & & & & \\
\hline & Mammalia (large) & Ig. mammal & 1 & & & & \\
\hline \multicolumn{2}{|c|}{ Shovel Test $12(\mathrm{~N}=4)$} & & $20 \operatorname{to} 40$ & & & & \\
\hline & Mammalia (large) & Ig. mammal & 3 & & & & \\
\hline & Mammalia (very large) & very lg. mammal & 1 & & & & \\
\hline \multirow{2}{*}{\multicolumn{2}{|c|}{ Shovel Test $15(\mathrm{~N}=1)$}} & & & & & & \\
\hline & & & Oto20 & & & & \\
\hline & Mammalia (large) & Ig. mammal & 1 & & & & \\
\hline \multicolumn{2}{|c|}{ Shovel Test $17(\mathrm{~N}=24)$} & & 20 to 40 & 40 to 60 & 60 to 80 & 80 & 80 to 85 \\
\hline & Vertebrata (indeterminate) & unidentifiable & & 1 & & & \\
\hline & Trionyx sp. & softshell turtle & & 1 & & & \\
\hline & Mammalia (small) & sm. mammal & & & 1 & & 2 \\
\hline & Mammalia (large) & Ig. mammal & 1 & & 9 & & 5 \\
\hline & Mammalia (very large) & very lg. mammal & 1 & & & & 1 \\
\hline & Sus scrofa & pig & & & 1. & & \\
\hline & Odocoileus sp. & deer & & & & 1 & \\
\hline \multicolumn{2}{|c|}{ Shovel Test $22(\mathrm{~N}=26)$} & & Oto20 & $20 t 040$ & 40 to60 & $60 t o 80$ & 80 to 100 \\
\hline & Mammalia (small) & sm. mammal & & 1 & & & \\
\hline & Mammalia (large) & lg. mammal & 1 & 1 & 1 & 20 & 1 \\
\hline & Odocoileus sp. & deer & & & 1 & & \\
\hline Shovel Test 2 & $24(N=1)$ & & $20 t 040$ & & & & \\
\hline & Sus scrofa & pig & 1 & & & & \\
\hline Midden ( $N=13$ & & & gen colle & ection & & & \\
\hline & Osteichthyes & med. fish & 4 & & & & \\
\hline & Terrapene sp. & box turtle & 1. & & & & \\
\hline & Mammalia (small) & sm. mammal & 1 & & & & \\
\hline & Mammalia (large) & Ig. mammal & 5 & & & & \\
\hline & Sus scrofa & pig & 1 & & & & \\
\hline & Odocoileus sp. & deer & 1 & & & & \\
\hline
\end{tabular}


Table 10. Distribution of faunal specimens by depth.

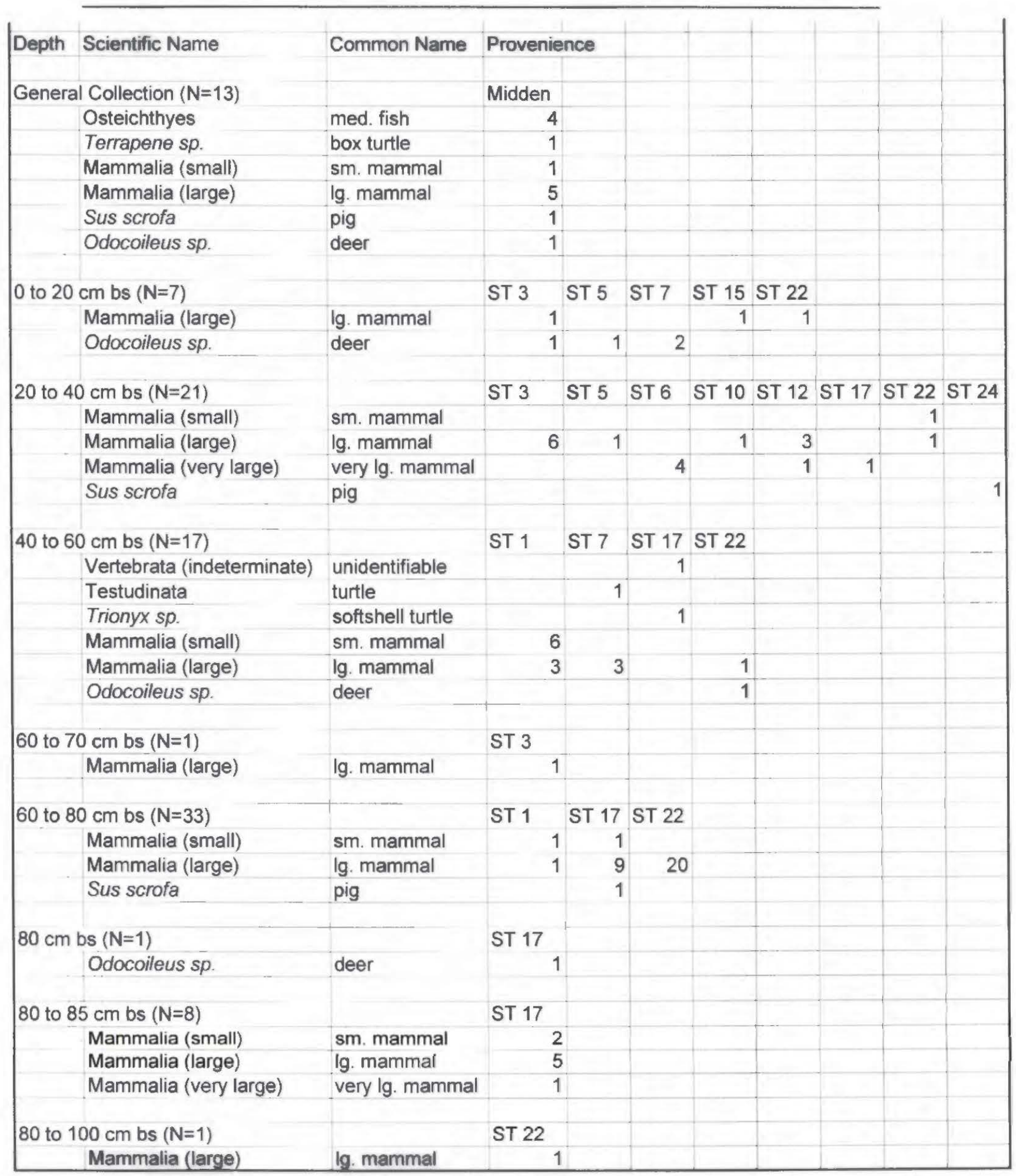

Also taxonomically diverse and high in quantity is the sample from ST 17 $(n=24)$, which is comprised of indeterminate vertebrate, softshell turtle, 
unidentifiable small, large, and very large mammal, pig, and deer. The remaining nine shovel tests range in quantities from one to 11 specimens each.

Level $1(0-20 \mathrm{~cm}$ bs) produced three large mammal and four deer bones from five shovel tests. Eight shovel tests in level $2(20-40 \mathrm{~cm}$ bs $)$ yielded 21 bone fragments, consisting of one small mammal, 12 large mammal, six very large mammal, and one pig. Seventeen faunal specimens from four shovel tests in level $3(40-60 \mathrm{~cm} \mathrm{bs})$ include indeterminate vertebrate, unidentifiable turtle, softshell turtle, small and large mammal, and deer. Vertically, level 4 yielded the majority of faunal specimens at the Edwards Creek site. This includes one large mammal bone from ST $3(60-70 \mathrm{~cm}$ bs), and the immature deer femur from ST $17(80 \mathrm{~cm}$ bs). Thirty unidentifiable large mammal bones, two small mammal bones, and one pig tooth fragment were recovered from three shovel tests at 60 to $80 \mathrm{~cm}$ bs. Level $5(80-100 \mathrm{~cm}$ bs) deposits in two shovel tests produced nine fragments from unidentifiable small, large, and very large mammal.

\section{Summary of the Faunal Analysis}

The Edwards Creek Site faunal assemblage reflects the exploitation of native animals and domestic meat sources typical of both East Texas settlers and Caddo Indians over time. The collection is dominated by unidentifiable large mammal remains, but pig and deer were probably important subsistence items. Small animals such as turtle and fish probably supplemented the diet as well.

\section{SUMMARY OF THE ARCHAEOLOGICAL FINDINGS}

Surface collections and a fairly extensive shovel testing effort were completed at the Edwards Creek site in 2005 once a midden stain was noted in a number of gopher mounds across an elevated area near Edwards Creek, in Freestone County, Texas. Shovel testing indicated that the midden covered about 800 square meters, while the site itself extends over 7 acres on an upland toe slope along Edwards Creek, a small northeastward-flowing tributary to the Trinity River. The artifacts recovered from the site-which include early $19^{\text {th }}$ century historic ceramics, nails, and bottle glass, aboriginal sherds, and chipped stone tools and the debris from the manufacture of chipped stone tools, as well as faunal remains from wild game and domesticated pig - were concentrated in and immediately adjacent to the midden, and the midden was found to extend to a maximum of $91 \mathrm{~cm}$ bs; the midden is buried a minimum of $20 \mathrm{~cm}$ bs and a maximum of $55 \mathrm{~cm}$ bs. One shovel test (ST 17) was placed in an apparent pit feature, most likely an outdoor cooking feature or earth oven, although it could be a hearth inside a structure.

Conventional archaeological interpretations may suggest that the midden was a product of occupations during both prehistoric and historic times. The prehistoric occupations - based strictly on the occurrence of temporally 
"diagnostic" projectile points - suggests that the Edward Creek site was used during Woodland (i.e., Gary dart points) and Late Prehistoric (i.e., Catahoula and Perdiz) periods, between ca. 2500 and 300 years ago. The Perdiz point came from deep in the midden, as did a few plain and decorated Caddo pottery sherds, suggesting that the midden may have begun to accumulate about $600-300$ years ago, the age range generally accepted of when Perdiz points were made and used. The other projectile points either were found on the surface or in a shovel test not excavated in the midden deposits. Following this same scenario, then, the historic early $19^{\text {th }}$ century occupation at the Edwards Creek site would have been unassociated with any of the aboriginal artifacts recovered from the midden, and the artifacts from that occupation became incorporated in the midden deposits by happenstance.

One problem with the interpretation that there is no obvious relationship-either temporally or spatially-between the historic component and the aboriginal artifacts is that the depth and thickness of the midden suggests, in fact, that much of the midden (if not all) at the site was deposited during the early $19^{\text {th }}$ century, the aboriginal artifacts along with it. Perhaps then the Perdiz point and Caddo pottery sherds were incorporated by chance in the midden when it was being accumulated in historic times, or the excavation of pits and earth ovens by the historic occupants of the Edwards Creek site dislodged these ostensibly prehistoric aboriginal artifacts from an occupation that underlain the midden. This is certainly a plausible argument, and there is no evidence to refute it at present. Nevertheless, we think it is worthwhile to consider and acknowledge the other possibility: namely, that the early $19^{\text {th }}$ century European and American goods, the faunal remains, the possible pit features from outdoor cooking activities, the midden deposits, and some of the aboriginal artifacts (especially the Caddo sherds) are part and parcel of a ca. 1820-1840 aboriginal Caddo occupation along the Trinity River.

One reason that we cannot rule this possibility out of hand rests in the historical record. In 1828, Jose Maria Sanchez, a draftsman accompanying General Manuel de Mier y Teran on an inspection tour of the Mexican province of Texas mentioned the following when the inspection tour crossed the Trinity River, not far to the south of Freestone County: "An Indian village of Nadacos was located near Galindo's house [on the east side of the Trinity River]. It is a peaceful tribe, comprising only twenty-nine families" (Sanchez 1926:279). Perhaps the Edwards Creek site early $19^{\text {th }}$ century occupation is the product of a fairly intensive occupation by Caddos who had already moved west from the Pineywoods to escape American colonists bent on driving the Caddo from their traditional homelands (Smith 2005:120).

To evaluate the possibility that much of the archaeological deposits at the Edwards Creek site are from an early $19^{\text {th }}$ century aboriginal Caddo occupation, further archaeological investigations will need to be conducted at the site to obtain additional evidence bearing on the ethnic affiliation and age of the $19^{\text {th }}$ century material culture 
remains found there. Further archaeological investigations at the Edwards Creek site should include metal detecting to uncover other European and American metal goods, along with extensive shovel testing to locate other habitation deposits, and controlled excavations in productive midden and habitation deposits. Remote sensing surveys of key areas of the site may also be warranted to identify anomalies or possible features of aboriginal or Anglo-American origin.

Controlled excavations provide the best opportunity to obtain a representative sample of the material culture remains discarded at the site, especially the recovery of a larger sample of aboriginal ceramic vessel sherds and American and English refined earthenwares. Hopefully future excavations may recover glass trade beads, cut and worked iron, silver, copper, and brass artifacts, as well as other kinds of trade goods that would have been available to aboriginal Caddo groups living in East Texas between ca. 1820-1840, and thus would not be expected on an Anglo-American farmstead. Aboriginal Caddo sherds can be subjected to thermoluminescence dating to establish the absolute age of the vessel that the sherd came from-which could provide incontrovertible evidence that the site was occupied in the early $19^{\text {th }}$ century by a Caddo group, as would the recovery of any diagnostic decorated Caddo historic ceramic wares in a larger ceramic assemblage. Lastly, controlled excavations may encounter architectural (wattle and daub covered structures, circular structures, ramadas or elevated work platforms, granaries, etc.) and pit features (i.e., smudge pits and outdoor earth ovens and cooking pits) preserved at the Edwards Creek site like those documented at other historic Caddo sites in East Texas that would shed light on the ethnic affiliation of the early $19^{\text {th }}$ century occupation.

\section{ACKNOWLEDGMENTS}

Figures were prepared by Sandy Hannum and T. Clay Schultz. Photographs of the artifacts were taken by Bo Nelson. We thank the landowner for permission to carry out these limited investigations at the Edwards Creek site.

\section{REFERENCES CITED}

Arbingast, S. A., L. G. Kennamer, R. H. Ryan, J. R. Buchanan, W. L. Hezlep, L. T. Ellis, T. G. Jordan, C. T. Granger, and C. P. Zlatkovich

1976 Atlas of Texas. Bureau of Business Research, The University of Texas at Austin.

Behler, J. L.

1995 National Audubon Society Field Guide to North American Reptiles and Amphibians. Chanticleer Press, New York. 
Brooks, R. L.

2007 Subsistence Practices of an Early Post-Removal Choctaw Homestead. MS on file, Oklahoma Archeological Survey, Norman.

Bureau of Economic Geology

1968 Geological Atlas of Texas, Palestine Sheet. Bureau of Economic Geology, The University of Texas at Austin.

Burt, W. H. and R. P. Grossenheider

1980 A Field Guide to the Mammals. $3^{\text {rd }}$ Edition. Peterson Field Guide Series, edited by R. T. Peterson, Houghton Mifflin Co., Boston.

Carr, J. T., Sr.

1969 The Climate and Physiography of Texas. Report 53. Texas Water Development Board, Austin.

Chaplin, R. E.

1971 The Study of Animal Bones from Archaeological Sites. Seminar Press, New York.

Coffee, D. J.

1975 Soil Survey of Anderson County. U. S. Department of Agriculture, Soil Conservation Service, in cooperation with Texas Agricultural Experiment Station, Washington, D.C.

Conant, R.

1975 A Field Guide to Reptiles and Amphibians of Eastern and Central North America. $2^{\text {nd }}$ Edition. Peterson Field Guide Series, Houghton Mifflin Co., Boston.

Davis, W. B.

1978 The Mammals of Texas. Bulletin No. 41, revised edition. Texas Parks and Wildlife Department, Austin.

Diamond, D. D., D. H. Riskind, and S. C. Orzell

1987 A Framework for Plant Community Classification and Conservation in Texas. Texas Journal of Science 39:203-221.

Fenneman, N. M.

1938 Physiography of Eastern United States. McGraw-Hill Book Company, Inc., New York. 
Janak, E. F. and E. L. Griffin

2002 Soil Survey of Freestone County, Texas. United States Department of Agriculture, Natural Resources Conservation Service, in cooperation with the Texas Agricultural Experiment Station and the Texas State Soil and Water Conservation Board.

Jurney, D. H. (editor)

1992 Archeological Survey, Historic Site Evaluations, \& Excavations at the Jewett Mine, Leon \& Freestone Counties, Texas: 1989 Field Season. Archaeology Research Program, Institute for the Study of Earth and Man, Southern Methodist University, Dallas.

Kenmotsu, N. A. and T. K. Perttula (editors)

1993 Archeology in the Eastern Planning Region, Texas: A Planning

Document. Cultural Resource Management Report 3. Department of Antiquities Protection, Texas Historical Commission, Austin.

Leibowitz, J.

1985 Yellow Ware: The Transitional Ceramic. Schiffer Publishing, Ltd., West Chester, Pennsylvania.

Majewski, T. and M. J. O'Brien

1987 The Use and Misuse of Nineteenth-Century English and American Ceramics in Archaeological Analysis. In Advances in Archaeological Method and Theory, Volume 11, edited by M. B. Schiffer, pp. 97-209. Academic Press, New York.

McGregor, D. E. and J. E. Bruseth (editors)

1987 Hunter-Gatherer Adaptations along the Prairie Margin: Site Excavations and Synthesis of Prehistoric Archaeology. Richland Creek Technical Series, Volume III. Archaeology Research Program, Institute for the Study of Earth and Man, Southern Methodist University, Dallas.

Miller, G. L. and R. R. Hunter, Jr.

1990 English Shell Edged Earthenware: Alias Leeds Ware, Alias Feather Edge. $35^{\text {th }}$ Annual Wedgwood International Seminar, pp. 107-136.

1994 English Shell-Edged Earthenware. Antiques CXLV(3):432-443.

Munzel, S.

1986 Quantitative Analysis and the Reconstruction of Site Patterning. Paper presented at the Vth International Conference of the International Council for ArchaeoZoology, Aug. 25-30, Bordeaux. 
Nelson, B. and T. K. Perttula

2003 Archeological Survey along the Lake Bob Sandlin Shoreline, Camp, Franklin, and Titus Counties, Texas. Report of Investigations No. 46. Archeological and Environmental Consultants, LLC, Austin.

Newcomb, W.W., Jr.

1993 The Indians of Texas from Prehistoric to Modern Times. University of Texas Press, Austin.

Newman, T. S.

1970 A Dating Key for Post-Eighteenth Century Bottles. Historical Archaeology 4(1):70-75.

Olsen, S. J.

1964 Mammal Remains from Archaeological Sites, Part I: Southeastern and Southwestern United States. Papers of the Peabody Museum of Archaeology and Ethnology, Volume 56, No. 1. Harvard University, Cambridge.

Parsons, M. L., J. E. Bruseth, J. Bagur, S. E. Goldborer, and C. McCrocklin 2002 Finding Sha' chahdinnih (Timber Hill): The Last Village of the Kadohadacho in the Caddo Homeland. Archeological Reports Series No. 3. Texas Historical Commission, Austin.

Perttula, T. K. (editor)

1989 The James Franks Site (41DT97): Excavations at a Mid-Nineteenth Century Farmstead in the South Sulphur River Valley, Cooper Lake Project, Texas. Contributions in Archaeology No. 7. Institute of Applied Sciences, University of North Texas, Denton.

Perttula, T. K. and B. Nelson

2005 Archeological Survey of Proposed Leonard Lake, Freestone County, Texas. Report of Investigations No. 72. Archeological \& Environmental Consultants, LLC, Austin.

Perttula, T. K., R. C. Fields, J. E. Corbin, and N. A. Kenmotsu

1993 The Emergence of Sedentism in Northeast Texas, ca. 500 B.C. to A.D. 1000. In Archeology in the Eastern Planning Region, Texas: A Planning Document, edited by N. A. Kenmotsu and T. K. Perttula, pp. 97-120. Cultural Resource Management Report 3. Department of Antiquities Protection, Texas Historical Commission, Austin.

Richner, J. J.

1982 Tennessee Colony III. Archaeology Research Program, Southern Methodist University, Dallas. 
Richner, J. J. and J. T. Bagot (assemblers)

1978 A Reconnaissance Survey of the Trinity River Basin, 1976-1977. Research Report 113. Archaeology Research Program, Southern Methodist University, Dallas.

Richner, J. J. and R. Lee

1976 Cultural Resources at Tennessee Colony Lake. Research Report 85. Archaeology Research Program, Southern Methodist University, Dallas.

1977 Archaeological and Ethnohistorical Survey at Tennessee Colony Lake 1975. Research Report 104. Archaeology Research Program, Southern Methodist University, Dallas.

Samford, P. M.

1997 Response to a Market: Dating English Underglaze Transfer-Printed Wares. Historical Archaeology 31(2):1-30.

Sanchez, J. M.

1926 A Trip to Texas in 1828. Translated by C. E. Castaneda. Southwestern Historical Quarterly XX1X(4):249-288.

Schambach, F. F.

1982 An Outline of Fourche Maline Culture in Southwest Arkansas. In Arkansas Archeology in Review, edited by N. L. Trubowitz and M. D. Jeter, pp. 132-197. Research Series No. 15. Arkansas Archeological Survey, Fayetteville.

Schmidly, D. J.

1983 Texas Mammals East of the Balcones Fault Zone. Texas A\&M University Press, College Station.

2002 Texas Natural History: A Century of Change. Texas Tech University Press, Lubbock.

Smith, F. T.

2005 From Dominance to Disappearance: The Indians of Texas and the Near Southwest, 1786-1859. University of Nebraska Press, Lincoln.

Story, D. A.

1990 Cultural History of the Native Americans. In The Archeology and Bioarcheology of the Gulf Coastal Plain, by D. A. Story, J. A. Guy, B. A. Burnett, M. D. Freeman, J. C. Rose, D. G. Steele, B. W. Olive, and K. J. Reinhard, pp. 163-366. 2 Vols. Research Series No. 38. Arkansas Archeological Survey, Fayetteville. 
Wells, T.

2000 Nail Chronology: The Use of Technologically Derived Features. In Approaches to Material Culture Research for Historical Archaeologists, compiled by D. R. Brauner, pp. 318-339. Society for Historical Archaeology, California, Pennsylvania. 